Article

\title{
Development of a Mass and Energy Balance Model and Its Application for HBI Charged EAFs
}

\author{
Niloofar Arzpeyma ${ }^{1,2, *}$, Rutger Gyllenram ${ }^{1,2}$ and Pär G. Jönsson ${ }^{1}$ \\ 1 Department of Materials Science and Engineering, Royal Institute of Technology (KTH), 10044 Stockholm, \\ Sweden; rutger.gyllenram@kobolde.com (R.G.); parj@kth.se (P.G.J.) \\ 2 Kobolde \& Partners AB, 11860 Stockholm, Sweden \\ * Correspondence: arzpeyma@kth.se; Tel.: +46-737-585-050
}

Received: 4 February 2020; Accepted: 26 February 2020; Published: 27 February 2020

check for updates

\begin{abstract}
A static mass and energy balance model combined with a $\mathrm{MgO}$ saturation slag model is developed for electric arc furnaces. The model parameters including distribution ratios and dust factors are calibrated for a specific furnace using experimental data. Afterward, the model is applied to study the effect of charging different amounts of hot briquetted iron (HBI) on energy consumption, charged slag former amount, and slag composition. The following results were obtained per each $1 \%$ increase of HBI additions: (i) a $0.16 \mathrm{Nm}^{3} / \mathrm{t}$ decrease in the amount of injected oxygen for metal oxidation, (ii) a $1.29 \mathrm{kWh} / \mathrm{t}$ increase in the electricity consumption, and (iii) a $34 \mathrm{~kg}$ increase in the amount of the slag.
\end{abstract}

Keywords: HBI; mass balance; energy balance; $\mathrm{MgO}$ saturation

\section{Introduction}

Many studies focusing on electric arc furnace (EAF) operations have been carried out during the last 30 years in order to improve the steel quality and to make the melting process more efficient, economical and environmentally friendly [1-3]. Any improvement to an EAF requires an extensive study of that specific furnace since each furnace is used to produce different steel grades. Apart from installations of equipment such as electromagnetic or inert gas stirrers and advanced oxygen-fuel injectors, even a small modification in the carbon and oxygen injection or in the raw material selection and tuning can result in an improved steel quality and productivity as well as in reduced energy consumption. The focus of this work is on one of these approaches, which is the importance of the material selection with an emphasis on charging hot briquetted iron (HBI) as a secondary complement to scrap. The quality of direct reduced iron (DRI) and HBI materials is more consistent compared to steel scraps since they are produced from iron ore. They can be used in electric arc furnaces to contribute to reduced levels of tramp elements such as copper, nickel and tin, which exist in scraps that are used as raw materials and [3-5]. The amount of the charged DRI and HBI materials is highly dependent on the scrap quality and the limits of tramp elements in the target steel grades. In addition, the usage of DRI/HBI can affect energy consumption, tap-to-tap time, and the iron yield [6-9].

Mass and energy balance models are used to calculate the energy consumption, melt composition and tapping time in EAFs [10-15]. A static EAF model based on mass and energy was proposed by Köhle based on operational data from 14 EAFs in Germany [10]. The model estimated the electrical energy consumption as a function of raw materials, slag formers, other sources of energy inputs as well as power-on and power-off times. Bekker et al. [11] and McRosty et al. [12] developed dynamic models of the EAF based on the heat and mass transfer between the three phases of melt, slag, and gas.

A more complex dynamic model was developed by Logar et al. [13], which considered more parameters with respect to the heat transfer between all phases as well as post-combustion. The average 
predicted power-on time, tapping temperatures and final Fe weights had differences of $0.2 \mathrm{~min}, 3 \mathrm{~K}$, and $1 \mathrm{t}$, respectively, compared to the data obtained from the production furnace. This is considered to be a good agreement, which illustrates that a dynamic model can give an accurate prediction of an EAF process. Hay et al. [14] improved the accuracy of the model developed by Logar et al. [13] by considering the equilibria between the metallic and oxidic elements and the dissolved oxygen in the bath and also by introducing a new zone at the metal and slag interface to the model in order to include the interfacial reactions.

Kirschen et al. [15] used a dynamic energy-mass balance in an EAF to study the effect of the amount of charged DRI with a metallization degree of $93 \%$ on the EAF energy efficiency. The results showed an increase of $1.19 \mathrm{kWh} / \mathrm{t}$ of the required electrical energy, a slight increase of injected oxygen amount, $0.046 \mathrm{~m}_{\mathrm{O}_{2}}^{3} / \mathrm{t}$, and a $13 \%$ decrease of the metal yield under a constant tap weight and slag basicity per each percent increase of DRI additions. The authors suggested that the increase of the required electrical energy could be compensated by the chemical energy due to exothermic reactions when the injected oxygen reacted with dissolved alloying elements originating from scrap.

The aim of this work is to develop a static mass and energy balance model of an EAF operation, integrated with a $\mathrm{MgO}$ saturation slag model as a web application. Real furnace data are used to calibrate the model parameters for that furnace and to determine the model accuracy. Afterward, the model is applied in order to evaluate the effect of HBI proportions in charged materials on the energy requirements, slag quantities, and compositions.

\section{Model Development}

A black-box approach is applied by using the mass and energy inputs and outputs inside EAFs considering the three states of solid, liquid and gas. The static mass and energy balance and slag model calculations are implemented as a Java web application called RAWMATMIX ${ }^{\circledR}$ (Version 2.16, Kobolde \& Partners AB, Stockholm, Sweden). The main input data are the quantities of raw materials and slag formers, distribution factors of metallic elements, tapping temperature, final carbon concentration, oxygen injection volume, burner energy, and refractory dissolutions into melt and slag. Besides, the desired values of slag properties are assigned. An outline of the workflow in RAWMATMIX ${ }^{\circledR}$ is shown in Figure 1.

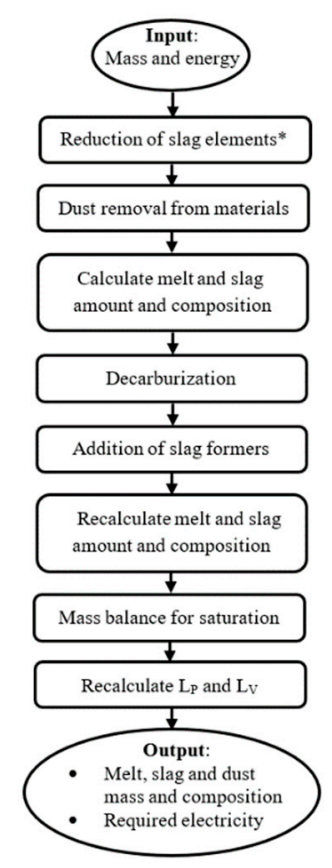

Figure 1. A flowchart of the calculation procedure used in RAWMATMIX ${ }^{\circledR}$. * The reduced slag elements are $\mathrm{MnO}, \mathrm{Cr}_{2} \mathrm{O}_{3}, \mathrm{FeO} / \mathrm{Fe}_{2} \mathrm{O}_{3}, \mathrm{P}_{2} \mathrm{O}_{5}$, and $\mathrm{VO}_{2}$. 


\section{Model Description}

The mass and energy balance applied in the model is described below:

\subsection{Mass Balance}

The mass balance is written by considering that all components in input materials and output products in an EAF can be written as follows:

$$
\sum_{j}^{\forall j} \sum_{i=1}^{\forall i} M_{i}^{j}=\sum_{p=1}^{\forall p} \sum_{i=1}^{\forall i} M_{i}^{p}
$$

where $M_{i}^{j}$ and $M_{i}^{p}$ are the mass of component $i$ in material $j$ and in product $p$, respectively.

The mass input originates from the following sources:

- Raw materials, which include different types of scraps, DRI/HBIs, and carbon powders

- Hot heel

- Slag formers, consisting of lime and dolomite

- Refractory components, which can be dissolved into slag

- Oxygen injected through lances and consumed during the metal oxidation, decarburization, powder carbon oxidation, fuel combustion in burners and post-combustion

- Fuel additions through the burners

The output mass includes the following products:

- Molten steel

- Molten slag, which can also, possibly, contain solid MgO components

- Hot heel

- Dust components in metal oxide forms

- Gas, which can consist of $\mathrm{CO}, \mathrm{CO}_{2}$, and $\mathrm{N}_{2}$.

The hot heel amount has been considered as both input and output since it can have different masses and compositions. The overall mass balance can be written as follows:

$$
m_{\text {Raw }}+m_{S F}+m_{I H H}+m_{P C I}+m_{O}+m_{\text {Fuel }}+m_{E l}+m_{R}=m_{\text {Dust }}+m_{\text {melt }}+m_{\text {slag }}+m_{R H H}+m_{\text {gas }}
$$

where $m_{\text {Raw }}, m_{S F}, m_{I H H}, m_{P C l}, m_{O}, m_{\text {Fuel }}, m_{E l}, m_{R}, m_{D u s t}, m_{m e l t}, m_{\text {slag }}, m_{R H H}$ and $m_{\text {gas }}$ are the mass of the raw material, slag formers, input hot heel, powder carbon, oxygen, fuel, refractory, dust, melt, slag, residual hot heel, and gas, respectively.

\subsubsection{Reactions}

The following assumptions are taken into account in the static model:

- Oxidation of metallic elements present in steel that goes into the slag, which has the following general form for element $X$ :

$$
[\mathrm{X}]+[\mathrm{O}] \rightarrow(\mathrm{XO})
$$

- $\quad$ Reduction of iron, manganese, chromium, phosphorus and vanadium oxides (XO):

$$
(\mathrm{XO}) \rightarrow[\mathrm{X}]+[\mathrm{O}]
$$




\subsubsection{Metal and Slag Composition}

The concentration of element $i$ in the melt, $C_{i}^{\text {melt }}$, is calculated as follows:

$$
C_{i}^{\text {melt }}=\frac{d_{i} M_{\text {input }} C_{i}^{\text {input }}}{M_{\text {melt }}}
$$

where $C_{i}^{\text {input }}$ is the concentration of component $i$ in the total mass input, $M_{\text {input }}$ is the total input mass, $d_{i}$ is the yield or distribution factor for element $i$, and it is a function of distribution ratio as follows [16]:

$$
d_{i}=\frac{1}{1+\frac{m_{\text {slag }}}{m_{\text {melt }}} L_{i}}
$$

where $L_{i}$ the distribution ratio of element $i$ between slag $(\% i)$ and melt $[\% i]$ and it is defined as follows:

$$
L_{i}=\frac{(\% i)}{[\% i]}
$$

and $M_{\text {melt }}$ is the mass of molten steel, which is defined as follows:

$$
M_{\text {melt }}=\sum_{i=1}^{\forall i} d_{i} C_{i}^{i n p u t}
$$

The concentration of the slag element of $i p$ in the slag, $C_{i p}^{\text {slag }}$, is calculated as follows:

$$
C_{i p}^{\text {slag }}=\frac{\left(1-d_{i}\right) S F_{i} M_{\text {input }} C_{i}^{\text {input }}}{M_{\text {slag }}}
$$

where $M_{\text {slag }}$ is the mass of the slag, which is defined as follows:

$$
M_{\text {slag }}=\sum_{i=1}^{\forall i}\left(1-d_{i}\right) C_{i}^{i n p u t}
$$

and $S F_{i}$ is the element-to-stoichiometric oxide conversion factor.

\subsubsection{Dust}

EAF dust contains mainly metal oxides, but also metallic elements. There are two main sources of dust in EAFs, namely dust in charged materials, $D_{1}$, and dust generated inside a furnace during the melting, refining and slag foaming stages of the furnace operation, $D_{2}$. The mass of $D_{1}$ is written as a function of the percentage of the fine material in each material $j, F F_{j}$, and the percentage of fine material lost to the dust, $F D$ :

$$
m_{D_{1}}=\sum_{j=1}^{\forall j} F D \cdot F F_{j} \cdot m_{j}
$$

For $D_{1}$, the concentration of removed dust from each material is the same as the material concentration. After removal of $D_{1}$, the mass of $D_{2}$ is calculated as a function of the percentage of the burnt metallic element, $D F_{i}$, inside the furnace. This is done as follows:

$$
m_{D_{2}}=\frac{\mathrm{M}_{p i}}{N_{i, p} \mathrm{M}_{i}}=\sum_{j=1}^{\forall j} \sum_{i=1}^{\forall i} D F_{i}\left(m_{j}-m_{D_{1}}^{j}\right) C_{i}^{j}
$$


where $m_{D, i}^{j}$ is the mass of the removed dust from each element in material $j$, and $m_{D_{1}}^{j}$ is the mass of dust removed from the material as fine material loss in the previous stage. $D F_{Z n}$ is considered to be $100 \%$.

The concentration of the total dust from each material $j$ after the second stage is calculated as follows, by adding the removed mass from each element to its previous mass resulting from the first stage:

$$
C_{D_{t}}^{j}=\sum_{i=1}^{\forall i} \frac{\left(m_{j}-m_{D_{1}}^{j}\right) C_{i}^{j}+m_{D, i}^{j}}{m_{D_{1}}+m_{D_{2}}}
$$

The total dust of the furnace is calculated by adding dust from each material. The current dust material contains both metals and metal oxides. In the next step, it is assumed that all metallic elements are oxidized in the hot atmosphere in an EAF so that the final composition of dust only contains oxides.

\subsection{Energy Balance}

The energy balance is made by considering the electrical, chemical energy and energy losses in EAFs, as described below. It is assumed that all output products reach the tapping temperature. The energy input includes all the following chemical energy inputs to the furnace:

- $\quad$ Enthalpy of charged material, $E_{m}$, which is described as follows:

$$
E_{m}=\sum_{m=1}^{\forall m} \sum_{i=1}^{\forall i}\left(\left(H_{i}^{298}+H_{i}^{m i x}+C_{p, i}^{298}(T-298)\right) n_{i}^{\text {charged }}\right)
$$

where $H_{i}^{298}$ is the enthalpy of formation of component $i$ at temperature $298 \mathrm{~K}$ and $H_{i}^{m i x}$ is the enthalpy of mixing. Furthermore, $n_{i}^{\text {charged }}$ is the mole number of component $i$ in the charged material, which is a mixture of scraps, DRI/HBI, slag formers, refractory and also hot heel which can be left from a previous heat.

A simplification is made to calculate the molar heat capacity, $C_{p, i}$, which is described as follows:

$$
H_{i}(T)=H_{i}^{T_{0}}+\int_{T_{0}}^{T} C p_{i}(T) d T=H_{i}^{T_{0}}+C p_{i}\left(T_{0}\right)\left(T-T_{0}\right)
$$

- Electricity, $E_{e l}$

- Energy of fuel combustion in burners, $E_{\text {burner }}$

- Energy of oxidation powder carbon, $E_{P C I}$

- Energy of cementite formation in DRI, $E_{c e m, D R I}$, which is calculated as follows:

$$
E_{c e m, D R I}=n_{\mathrm{Fe}_{3} \mathrm{C}} \cdot \mathrm{H}_{\mathrm{Fe}_{3} \mathrm{C}}^{298}
$$

The total input energy can be written as follows:

$$
E_{\text {input }}=E_{m}+E_{\text {el }}+E_{\text {burner }}+E_{P C I}+E_{c e m, D R I}
$$

The energy output consists of the following sources:

- Enthalpy of molten steel at the tapping temperature, $E_{\text {melt }}$

$$
E_{\text {melt }}=\sum_{i=1}^{\forall i}\left(H_{i}^{1700}+H_{i}^{\text {mix }}+C_{p, i}^{1700}(T-1700)\right) n_{i, m}^{\text {out }}
$$


- Enthalpy of molten slag at the tapping temperature, $E_{\text {slag }}$

$$
E_{\text {slag }}=E_{\text {melting }}+\sum_{i p=1}^{\forall i p}\left(H_{i}^{1700}+C_{p, i p}^{1700}(T-1700)\right) n_{i p, m}^{\text {out }}
$$

where $E_{\text {melting }}$ is the energy required to melt the slag.

Energy loss, $E_{\text {loss }}$. This consists of losses of energy due to the electrical energy loss, the energy loss through off-gases leaving the furnace, the energy loss during the opening of the roof, and the energy loss due to the water cooling of the furnace. In addition, these losses can take place during different modes of an EAF operation, including power on, $E_{l o s s, o n}$, power off, $E_{l o s s, o f f}$, and idle, $E_{\text {loss, idle }}$. To summarize, the energy loss is defined as follows:

$$
E_{\text {loss }}=E_{\text {loss }, 0 n}+E_{\text {loss }, \text { off }}+E_{\text {loss }, \text { idle }}=t_{o n} H_{\text {loss }, \text { on }}+t_{o f f} H_{\text {loss }, \text { off } f}+t_{\text {idle }} H_{\text {loss }, \text { idle }}
$$

where $H_{\text {loss,onn }}, H_{\text {loss,off }}, H_{\text {loss, idle }}$ are the heat losses when the EAF is operating in the on, off and idle modes, respectively. Furthermore, $t_{o n}, t_{o f f}$ and $t_{\text {idle }}$ are the power on, power off and idle times during the furnace operation, respectively.

The thermodynamic data for metallic elements and metal oxides are shown in Tables A1 and A2 [17] (Appendix A).

\subsection{Slag Model}

A MgO saturation slag model developed by Selin [18] is employed to estimate distribution factors for $\mathrm{P}$ and $\mathrm{V}$ and to estimate the solubility of $\mathrm{MgO}$ in the slag. The relative phosphorous distribution expressed by a variable, $\lambda_{P}$, using the following equation:

$$
\lambda_{P}=\frac{L_{p}}{L_{P}^{e q}}
$$

where $L_{p}$ is the distribution ratio of phosphorus between slag and melt and $L_{P}^{e q}$ is the equilibrium distribution ratio of phosphorus between slag and melt. When an equilibrium between slag and melt is reached $\left(L_{p}=L_{P}^{e q}\right), \lambda_{P}=1$. A similar correlation is also applied to the distribution of vanadium. Besides, the degree of $\mathrm{MgO}$ saturation is defined as follows:

$$
\lambda_{\mathrm{MgO}}=\frac{\% M g O^{\text {slag }}}{\% M g O^{\text {sat }}}
$$

where $\% M g \mathrm{O}^{\text {slag }}$ is the percentage of $\mathrm{MgO}$ in slag and $\% \mathrm{MgO}^{\text {sat }}$ is the $\mathrm{MgO}$ solubility in slag at saturation.

Selin [18] showed that the equilibrium distribution ratio for $\mathrm{P}$ and $\mathrm{V}$ and $\mathrm{MgO}$ saturation are functions of the percentages of the $\mathrm{P}_{2} \mathrm{O}_{5}, \mathrm{SiO}_{2}, \mathrm{Al}_{2} \mathrm{O}_{3}, \mathrm{TiO}_{2}$, and $\mathrm{VO}_{2}$ contents. These correlations are shown in the Appendix B [18]. The reference values of $\mathrm{MgO}, \mathrm{LP}$, and $\mathrm{LV}$ are calculated based on a simpler slag system, where the percentages of $\mathrm{FeO}$ and $\mathrm{CaO}$ are independent variables.

The initial distribution ratios for $\mathrm{P}$ and $\mathrm{V}$ are changed to reach the desired relative distribution ratios, dependent on the slag composition and temperature. The number of slag formers can be added as input materials, or they can be adjusted in order to reach the desired value for the concentrations of $\mathrm{FeO}$ and $\mathrm{CaO}$ in slag and the degree of $\mathrm{MgO}$ saturation, $\lambda_{\mathrm{MgO}}$.

\section{Model Calibration and Validation}

Some parameters in the model are required to be calibrated for each specific furnace. In this study, only one electric arc furnace is taken into account as described below. 


\subsection{Furnace Data}

The furnace has the maximum installed power of $40 \mathrm{MW}$ and a tap weight of $50 \mathrm{t}$. It is equipped with a continuous feeding system for hot briquetted iron (HBI) through its roof. It is typically charged by approximately 10 to $16 \%$ HBI along with the scraps. This HBI quality contains less carbon than DRI and more acidic components. The charging of a higher amount of HBI requires a new practice to add slag formers in order to control the $\mathrm{MgO}$ solubility, slag amount and metal yield. At the same time, energy consumption and productivity are important factors to take into account to operate the furnace in an efficient manner.

The steel and slag sampling, as well as the temperature measurements, are done when all the scraps and HBI have been melted. In this study, 16 heats are taken into account. First, the calculations are done in order to calibrate the model using 8 heats. Thereafter, the rest of the heats are used to validate the model predictions. The amounts and compositions of the input raw materials for each heat are presented in Tables A3 and A4 (Appendix A), respectively. The values are based on the data used for production planning at the plant, which is validated with a regression analysis of 1000 heats as well as by XRF determinations. The composition for HBI originates from the datasheet issued by the certification institute controlling the shipment.

The values applied for oxygen lancing, burner input (which corresponds to the recorded values for oxygen injection in a burner) and tapping temperature are shown in Table 1 for all 16 heats named as (1-8) used for calibration, and $(\mathrm{a}-\mathrm{h})$ used for validations.

Table 1. The oxygen lance, burner input and tap temperature for heats (1-8) and (a-h).

\begin{tabular}{ccccccccc}
\hline Heat & $\mathbf{1}$ & $\mathbf{2}$ & $\mathbf{3}$ & $\mathbf{4}$ & $\mathbf{5}$ & $\mathbf{6}$ & $\mathbf{7}$ & $\mathbf{8}$ \\
\hline Oxygen lance $\left(\mathrm{Nm}^{3}\right)$ & 110 & 116 & 260 & 137 & 225 & 275 & 81 & 104 \\
Burner $(\mathrm{kWh})$ & 500 & 620 & 480 & 480 & 460 & 730 & 745 & 735 \\
Tap temperature $\left({ }^{\circ} \mathrm{C}\right)$ & 1644 & 1693 & 1652 & 1613 & 1639 & 1619 & 1662 & 1649 \\
\hline Heat & $\mathbf{a}$ & $\mathbf{b}$ & $\mathbf{c}$ & $\mathbf{d}$ & $\mathbf{e}$ & $\mathbf{f}$ & $\mathbf{g}$ & $\mathbf{h}$ \\
\hline Oxygen lance $\left(\mathrm{Nm}^{3}\right)$ & 111 & 310 & 147 & 116 & 123 & 206 & 99 & 83 \\
Burner $(\mathrm{kWh})$ & 480 & 480 & 470 & 480 & 480 & 710 & 730 & 735 \\
Tap temperature $\left({ }^{\circ} \mathrm{C}\right)$ & 1681 & 1670 & 1651 & 1620 & 1660 & 1625 & 1658 & 1621 \\
\hline
\end{tabular}

\subsection{Calibration}

To make the model more practical to use, some values for the furnace and the target products are assigned to constant values. These are (i) the distribution ratios and phosphorus and vanadium allocation and, (ii) the percentage of element burnt off as dust (dust factors). The following estimations are done:

\subsubsection{Slag Composition}

The chemical composition of slag is normalized to a total value of 100 . The FeO content in the slag varies by 14 to $29 \mathrm{wt}$. \%. This is probably dependent on how the lance is introduced into the melt and it may not be representative for the slag chemical composition over the EAF tap-to-tap time. The slag composition is recalculated to reach an average value of $22 \mathrm{wt}$. \% for the FeO content in the slag, as shown in Table 2. 
Table 2. The chemical compositions of the of slag samples for the calibration heats in wt. \% (1-8).

\begin{tabular}{ccccccccc}
\hline Heat & $\mathbf{1}$ & $\mathbf{2}$ & $\mathbf{3}$ & $\mathbf{4}$ & $\mathbf{5}$ & $\mathbf{6}$ & $\mathbf{7}$ & $\mathbf{8}$ \\
\hline $\mathrm{MnO}$ & 2.79 & 2.45 & 2.07 & 3.43 & 3.80 & 4.13 & 2.59 & 2.28 \\
$\mathrm{P}_{2} \mathrm{O}_{5}$ & 0.45 & 0.35 & 0.25 & 0.43 & 0.43 & 0.44 & 0.41 & 0.41 \\
$\mathrm{~S}$ & 0.05 & 0.07 & 0.12 & 0.04 & 0.05 & 0.05 & 0.06 & 0.06 \\
$\mathrm{Cr}_{2} \mathrm{O}_{3}$ & 0.24 & 0.39 & 0.26 & 0.35 & 0.30 & 0.39 & 0.29 & 0.23 \\
$\mathrm{NiO}$ & 0.01 & 0.01 & 0.02 & 0.02 & 0.01 & 0.01 & 0.02 & 0.02 \\
$\mathrm{NbO}$ & 0.07 & 0.05 & 0.08 & 0.06 & 0.07 & 0.07 & 0.07 & 0.05 \\
$\mathrm{SiO}_{2}$ & 16.70 & 12.33 & 14.33 & 15.06 & 10.23 & 12.86 & 11.63 & 13.89 \\
$\mathrm{~V}_{2} \mathrm{O}_{5}$ & 0.08 & 0.09 & 0.11 & 0.09 & 0.08 & 0.08 & 0.10 & 0.15 \\
$\mathrm{TiO}_{2}$ & 1.15 & 0.75 & 0.65 & 1.28 & 0.95 & 0.74 & 1.38 & 1.43 \\
$\mathrm{Al}_{2} \mathrm{O}_{3}$ & 8.30 & 5.59 & 6.55 & 7.69 & 5.50 & 5.91 & 4.26 & 4.74 \\
$\mathrm{CaO}$ & 40.36 & 41.39 & 40.75 & 40.08 & 42.79 & 41.13 & 44.83 & 43.13 \\
$\mathrm{MgO}$ & 7.81 & 14.53 & 12.80 & 9.47 & 13.79 & 12.19 & 12.36 & 11.62 \\
$\mathrm{FeO}$ & 22 & 22 & 22 & 22 & 22 & 22 & 22 & 22 \\
\hline
\end{tabular}

\subsubsection{Slag Mass}

The slag mass is estimated for each heat. Thereafter, its average value is used to calculate the average distribution factor for each metallic element. The only sources for $\mathrm{CaO}$ are lime, dolomite, and $\mathrm{HBI}$ and all $\mathrm{CaO}$ ends up in the slag. Thus, the slag mass, $m_{s}$, is calculated as follows using a simple mass balance for $\mathrm{CaO}$ :

$$
m_{s} C_{\mathrm{CaO}, \mathrm{s}}+m_{\mathrm{CaO}, \mathrm{dust}}=m_{l} \mathrm{C}_{\mathrm{caO}, \mathrm{l}}+m_{d} \mathrm{C}_{c a \mathrm{O}, \mathrm{d}}+m_{\mathrm{HBI}} \mathrm{C}_{\mathrm{CaO}, \mathrm{HBI}}
$$

here $\mathrm{C}_{\mathrm{CaO}, s}$ is the concentration of $\mathrm{CaO}$ in the slag and $m_{l}$ is the mass of the charged lime, which is equal to $1000 \mathrm{~kg}$. The parameters $m_{d}$ and $m_{H B I}$ are the mass of dolomite and HBI, respectively Note that these values vary for each heat. Furthermore, $\mathrm{C}_{\mathrm{CaO}, l}, C_{c a \mathrm{O}, d}$ and $\mathrm{C}_{\mathrm{CaO}, \mathrm{HBI}}$ are the concentrations of $\mathrm{CaO}$ in lime, dolomite, and HBI, respectively. The parameter $m_{\mathrm{CaO}, \text { dust }}$ is the mass of $\mathrm{CaO}$ in the dust, which is calculated using the percentage of $\mathrm{Ca}$ in the chemical composition of the dust in the filter bag. Since the dust in the filter bag was not determined for any of the studied heats, an old chemical composition of the dust for the furnace was used.

\subsubsection{Metal Composition}

The chemical composition of the melt is shown in Table 3. The concentration of aluminum was around $0.3 \%$ in the metal chemical composition data, which does not correspond to the input materials having any or very low concentrations of aluminum. This aluminum mostly originates from aluminum-killed lollipop samples, containing aluminum. Therefore, the melt composition is normalized so that the concentration of aluminum becomes $0.05 \%$.

There is an average difference of around $90 \mathrm{~kg}$ between the input and output aluminum values when a new concentration of aluminum is used. The average aluminum oxide concentration in the slag is around $6 \%$. Running the calculation using the reported scrap composition resulted in an average concentration of $1 \%$ aluminum oxide. One reason for the difference in these values is due to that aluminum is present in coating materials in scraps. Therefore, its amount can be underestimated in scraps. Thus, A new concentration of aluminum for scraps is calculated, so that Old scrap 1, New scrap 1 and New scrap 2 contain $0.42 \%$ and $0.8 \%$ and $0.2 \% \mathrm{Al}$ respectively. 
Table 3. Calibrated chemical compositions of melts for the calibration heats in wt. \% (1-8).

\begin{tabular}{ccccccccc}
\hline Heat & $\mathbf{1}$ & $\mathbf{2}$ & $\mathbf{3}$ & $\mathbf{4}$ & $\mathbf{5}$ & $\mathbf{6}$ & $\mathbf{7}$ & $\mathbf{8}$ \\
\hline $\mathrm{C}$ & 0.615 & 0.740 & 0.592 & 0.449 & 0.175 & 0.332 & 0.342 & 0.333 \\
$\mathrm{Mn}$ & 0.105 & 0.109 & 0.122 & 0.084 & 0.098 & 0.114 & 0.074 & 0.067 \\
$\mathrm{P}$ & 0.005 & 0.008 & 0.006 & 0.003 & 0.003 & 0.004 & 0.003 & 0.003 \\
$\mathrm{~S}$ & 0.010 & 0.014 & 0.017 & 0.010 & 0.008 & 0.011 & 0.009 & 0.011 \\
$\mathrm{Cr}$ & 0.0249 & 0.058 & 0.068 & 0.026 & 0.016 & 0.026 & 0.023 & 0.019 \\
$\mathrm{Ni}$ & 0.020 & 0.033 & 0.049 & 0.022 & 0.022 & 0.028 & 0.022 & 0.020 \\
$\mathrm{Cu}$ & 0.018 & 0.051 & 0.064 & 0.026 & 0.019 & 0.028 & 0.023 & 0.021 \\
$\mathrm{Nb}$ & 0.004 & 0.004 & 0.003 & 0.004 & 0.004 & 0.004 & 0.004 & 0.004 \\
$\mathrm{Si}$ & 0.001 & 0.001 & 0.001 & 0.001 & 0.001 & 0.001 & 0.003 & 0.001 \\
$\mathrm{Mo}$ & 0.010 & 0.017 & 0.014 & 0.017 & 0.028 & 0.019 & 0.004 & 0.004 \\
$\mathrm{Sn}$ & 0.001 & 0.002 & 0.002 & 0.001 & 0.001 & 0.001 & 0.000 & 0.000 \\
$\mathrm{Ca}$ & 0.001 & 0.001 & 0.001 & 0.001 & 0.001 & 0.001 & 0.001 & 0.001 \\
$\mathrm{~V}$ & 0.001 & 0.001 & 0.001 & 0.001 & 0.001 & 0.001 & 0.001 & 0.001 \\
$\mathrm{~W}$ & 0.002 & 0.005 & 0.001 & 0.003 & 0.001 & 0.001 & 0.003 & 0.004 \\
$\mathrm{~Pb}$ & 0.006 & 0.007 & 0.006 & 0.006 & 0.006 & 0.006 & 0.006 & 0.006 \\
$\mathrm{Ti}$ & 0.002 & 0.001 & 0.001 & 0.001 & 0.002 & 0.001 & 0.002 & 0.001 \\
$\mathrm{Al}$ & 0.05 & 0.05 & 0.05 & 0.05 & 0.05 & 0.05 & 0.05 & 0.05 \\
$\mathrm{Zr}$ & 0.001 & 0.001 & 0.001 & 0.001 & 0.001 & 0.001 & 0.001 & 0.001 \\
$\mathrm{Fe}$ & 99.1 & 98.9 & 99 & 99.3 & 99.6 & 99.4 & 99.4 & 99.4 \\
\hline
\end{tabular}

\subsubsection{Distribution Ratios}

The slag and melt compositions are used to calculate the distribution ratios for metallic elements, as described in Equation (7). The result of the average distribution ratios and their standard deviations are shown in Table 4. To simplify the model, an average distribution ratio for each element is applied.

Table 4. The average calculated distribution ratios for all metallic elements and the standard deviations of distribution ratios for the calibration heats (1-8).

\begin{tabular}{ccc}
\hline Element $(i)$ & $\mathbf{L}_{\boldsymbol{i}}$ & $\boldsymbol{\sigma}_{\mathbf{L}}$ \\
\hline $\mathrm{Mn}$ & 24 & 7 \\
$\mathrm{~S}$ & 5.4 & 1.4 \\
$\mathrm{Cr}$ & 4.5 & 2 \\
$\mathrm{Ni}$ & 0.48 & 0.2 \\
$\mathrm{Cu}$ & 0 & 0 \\
$\mathrm{Nb}$ & 15.4 & 3.3 \\
$\mathrm{Si}$ & 1467 & 1405 \\
$\mathrm{Mo}$ & 0 & 0 \\
$\mathrm{P}$ & 49.2 & 22 \\
$\mathrm{Ti}$ & 453 & 191 \\
$\mathrm{~V}$ & 0.22 & 6.7 \\
$\mathrm{Al}$ & 111 & 28 \\
\hline
\end{tabular}

The values of $L_{P}^{e q}$ and $L_{V}^{e q}$ are calculated for all heats, based on the measured slag composition data and the correlations shown in the Appendix B. Furthermore, $L_{p}$ and $L_{V}$ are calculated using Equation (7), and $\lambda_{P}$ and $\lambda_{V}$ are calculated using Equation (21). Their average values are set as the relative distributions of $\mathrm{P}$ and $\mathrm{V}$ in the slag, which are 0.78 and 0.04 , respectively.

\subsubsection{Dust Calculation}

As mentioned earlier, the collected dust from the cyclone is recycled into the furnace. Thus, it can be neglected when determining the dust factors for the model. The average weight of the dust collected in the electro filter bag is around $28 \mathrm{~kg} / \mathrm{t} \mathrm{steel,} \mathrm{which} \mathrm{is} \mathrm{an} \mathrm{estimated} \mathrm{value} \mathrm{based} \mathrm{on} \mathrm{the} \mathrm{yearly}$ collection. The composition of the dust material in the filter bag is shown in Table 5. Since the dust 
does not contain any $\mathrm{MgO}, \mathrm{Al}_{2} \mathrm{O}_{3}$, and $\mathrm{SiO}_{2}$, it cannot be defined as dust removed from lime, dolomite or HBI. However, these three materials are the only ones that contain CaO. Moreover, in this model, the $\mathrm{CaO}$ can only end up in the dust during the first stage of dust removal, which is from charged materials. Thus, the dust composition is adjusted so that it contains $\mathrm{MgO}, \mathrm{Al}_{2} \mathrm{O}_{3}$, and $\mathrm{SiO}_{2}$ originating from lime and dolomite. The following two equations are applied to calculate the percentages of fine materials in lime and dolomite, $F F_{\text {lime }}$ and $F F_{\text {dolomit }}$.

$$
\begin{aligned}
m_{\mathrm{CaO}, \text { dust }} & =C_{\mathrm{CaO}, \text { lime }} * \bar{M}_{\text {lime }} * F F_{\text {lime }}+C_{\mathrm{CaO}, \text { dolomite }} * \bar{M}_{\text {dolomite }} * F F_{\text {dolomit }} \\
m_{\mathrm{MgO}, \text { dust }} & =C_{\mathrm{MgO}, \text { lime }} * \bar{M}_{\text {lime }} * F F_{\text {lime }}+C_{M g O, \text { dolomite }} * \bar{M}_{\text {dolomite }} * F F_{\text {dolomit }}
\end{aligned}
$$

where $\bar{M}_{\text {lime }}$ and $\bar{M}_{\text {dolomite }}$ are the average mass of charged lime and dolomite for all heats. The calculated values for $F F_{\text {Lime }}$ and $F F_{\text {dolomit }}$ are $6.2 \%$ and $1.8 \%$, respectively.

Table 5. The chemical composition of dust (wt. \%) in the filter bag.

\begin{tabular}{cccccccccc}
\hline $\mathbf{C}$ & $\mathrm{CaO}$ & $\mathrm{MnO}$ & $\mathrm{Cr}_{2} \mathbf{O}_{3}$ & $\mathrm{~S}$ & $\mathrm{Fe}_{2} \mathrm{O}_{3}$ & $\mathrm{ZnO}$ & $\mathrm{CuO}$ & $\mathrm{PbO}$ & $\mathrm{Cd}$ \\
\hline 0.01 & 4.77 & 1.732 & 0.1 & 0.02 & 41.14 & 44.96 & 0.06 & 7.2 & 0.001 \\
\hline
\end{tabular}

The other elements in the dust are assumed to be produced during the burning-off period in the furnace. Thus, the mass of each element in the dust is calculated using the dust composition and the dust weight in the filter bag. The amount of the calculated zinc in the dust using the average dust amount of $28 \mathrm{~kg} / \mathrm{t}$ becomes higher than the input zinc in scrap materials. This means there is an uncertainty in the chemical composition of zinc in some scraps. The percentage of the burnt metallic elements, $D F_{i}$ is calculated using Equation (12). It is assumed that $100 \mathrm{wt}$ \% of zinc is oxidized. The results are shown in Table 6.

Table 6. The average metallic element burnt off in wt. \%.

\begin{tabular}{ccccccc}
\hline Mn (\%) & Cr (\%) & Fe (\%) & $\mathrm{Cu} \mathrm{( \% )}$ & $\mathrm{Pb} \mathrm{( \% )}$ & $\mathrm{S} \mathrm{( \% )}$ & $\mathrm{Zn} \mathrm{( \% )}$ \\
\hline 11 & 5 & 0.8 & 13 & 71 & 6 & 100 \\
\hline
\end{tabular}

\subsubsection{Other Estimations}

The heat losses during the power-on periods, $H_{\text {loss, on }}$, and power-off periods, $H_{\text {loss, off }}$, are assumed to be 8 and $3 \mathrm{MW}$, respectively. The heat losses are adjusted to reach values as close as possible to the actual values for electricity consumption since there were no data available to estimate the heat losses.

$t_{\text {off }}$ is set to $35 \mathrm{~min}$ based on the average value for more than 1000 heats, and $t_{\text {on }}$ is calculated for each heat as follows:

$$
t_{\text {on }}=\frac{60 E_{e l}}{1000\left(P_{\text {on }}-H_{\text {loss }, \text { on }}\right)}
$$

where $E_{e l}$ is the electricity consumption of the furnace in $\mathrm{kWh}$, and $P_{o n}$ is the average power on, which is $40 \mathrm{MW}$ in all further calculations.

The refractory wear is estimated for each heat based on the estimated slag mass and using the $\mathrm{MgO}$ balance. The average refractory wear is around $3.0 \mathrm{~kg} / \mathrm{t}$, which is applied to the model. It is assumed that all charged materials have an initial temperature of $25^{\circ} \mathrm{C}$. The target decarburization is set as 0.45 for all heats, which corresponds to the average target carbon content in the melt analysis.

Around $5000 \mathrm{~kg}$ hot heel with a temperature of $1600^{\circ} \mathrm{C}$ is considered for all heats. The composition of the hot heel and sculls are defined as an average value of the chemical composition of each target product, based on the chemical composition data of the melt. The hot heel type for each heat and the chemical composition for each hot heel type are shown in Table A4 (Appendix A) and Table 1, respectively. 


\section{Model Application}

In order to study how an increased amount of HBI influences the slag and steel qualities, 7 cases are considered. The percentage of HBI varies between 13 to $40 \%$, as shown in Table 7 . Case 1 represents heat (1) and the other cases are created by reducing the scrap amounts and by increasing the HBI amounts. The amount of each scrap type is reduced so that its proportion to the total scrap amount is unchanged. The amounts of the pig iron types 1 and 2 and slag formers are the same as in heat (1) for all heats.

Table 7. The percentage of hot briquetted iron (HBI) and the amount of charged scrap for cases 1-7.

\begin{tabular}{cccccccc}
\hline Raw material & Case 1 & Case 2 & Case 3 & Case 4 & Case 5 & Case 6 & Case 7 \\
\hline HBI (\%) & 13 & 15 & 20 & 25 & 30 & 35 & 40 \\
Old scrap 1 $(\mathrm{kg})$ & 2400 & 2342 & 2190 & 2038 & 1887 & 1735 & 1583 \\
Old scrap 3 $(\mathrm{kg})$ & 3250 & 3172 & 2966 & 2760 & 2555 & 2349 & 2144 \\
New scrap 1 $(\mathrm{kg})$ & 12,400 & 12,101 & 11,316 & 10,532 & 9747 & 8963 & 8178 \\
New scrap 2 $(\mathrm{kg})$ & 12,400 & 12,101 & 11,316 & 10,532 & 9747 & 8963 & 8178 \\
New scrap 3 $(\mathrm{kg})$ & 11,200 & 10,930 & 10,221 & 9513 & 8804 & 8095 & 7387 \\
\hline
\end{tabular}

\section{Results and Discussion}

\subsection{Calibration Results}

\subsubsection{Slag}

The comparison between the estimated slag amounts ( $\mathrm{kg} / \mathrm{heat})$, based on the $\mathrm{CaO}$ balance explained in the previous section, and the calculated data using RAWMATMIX ${ }^{\circledR}$ is shown in Figure 2a.

The maximum absolute error between the calculated and estimated amounts is $315 \mathrm{~kg} / \mathrm{heat}$. A good agreement, with the Pearson correlation coefficient $(R)$ of 0.81 between the calculated and estimated values is obtained. In order to explain the discrepancy observed in slag amounts, differences between estimated and calculated oxide amounts in the slag are calculated. The oxides having high differences are $\mathrm{MgO}, \mathrm{Al}_{2} \mathrm{O}_{3}, \mathrm{MnO}, \mathrm{TiO}_{2}$, and $\mathrm{SiO}_{2}$. The sum of the differences in oxide amounts are depicted versus the differences in slag amounts, shown in Figure $2 b$. A very good relation, with a coefficient of determination $\left(R^{2}\right)$ of 0.995 is obtained when all the mentioned oxides are taken into account. The differences in the $\mathrm{MgO}$ amounts are resulted by using the average refractory wear for all heats. The differences in the $\mathrm{Al}_{2} \mathrm{O}_{3}$ amounts are due to the assumed concentration of $\mathrm{Al}$ in scraps. A comparison between the input and output amounts for $\mathrm{Mn}, \mathrm{Ti}$, and $\mathrm{Si}$ by using raw material compositions and measured melt compositions show differences between 2-130 kg, 7-17 kg, and $1-123 \mathrm{~kg}$, respectively. This means that there are uncertainties in the scrap compositions for these elements. A relation between the differences in $\mathrm{Mn}$ input and output amounts versus Old scrap 1 amount is found with a value of $R^{2} \approx 0.88$, shown in Figure 2c. It can be seen that heat (3) and heat (6) have the highest discrepancies between the inputs and outputs, which are charged with high amounts of Old scrap 1. For Ti, the highest differences in inputs and outputs are for heat (1), heat (4), heat (7) and heat (8), in which the input Ti amount is $15-17 \mathrm{~kg}$ lower than its output amount. These heats are the only heats charged by Old scrap 2 having a $0 \%$ Ti content in the raw material composition. It can be concluded that the Ti content in this scrap type is underestimated. The highest difference between the input and output $\mathrm{Si}$ values is observed for heat (5) (Input-output $=-123 \mathrm{~kg}$ ), which is charged by only New scrap types. The following relation is obtained between the sum of Old scrap 1, New scrap 1 and New scrap 3 amounts and differences in Si inputs and outputs considering all heats:

$$
m_{S i}^{\text {input }}-m_{S i}^{\text {output }}=-0.007\left(m_{\text {Old } 1}+m_{\text {New } 1}+m_{\text {New 3 }}\right)+190, R^{2}=0.67
$$

This suggests that these three scrap types have uncertainties with respect to the Si content. However, better identification of uncertainties in scrap composition requires more data. 


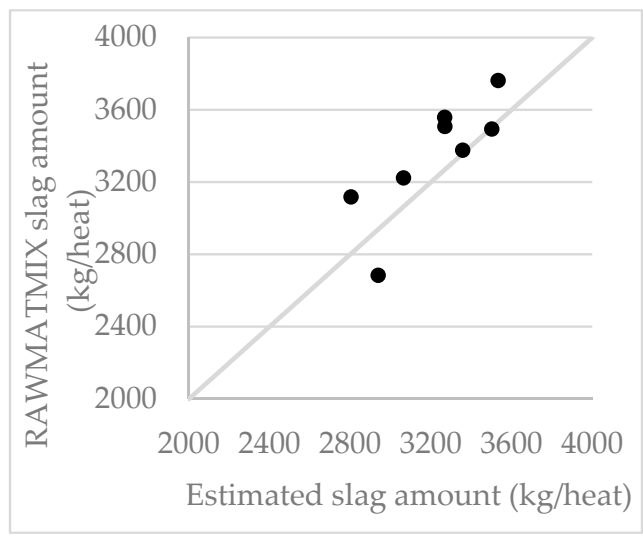

(a)

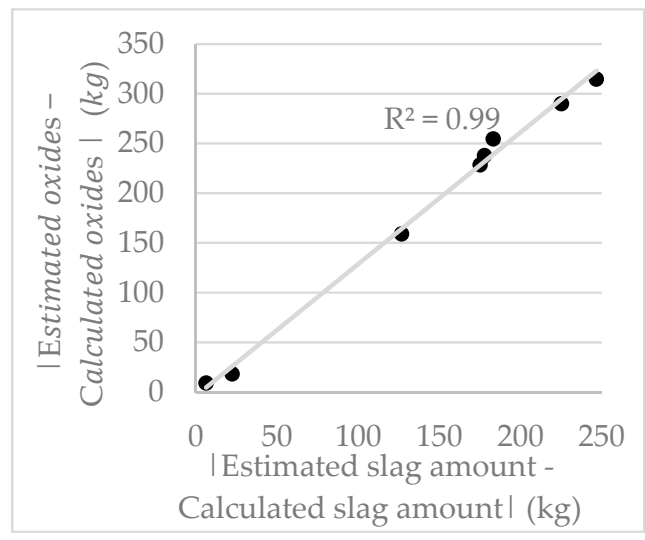

(b)

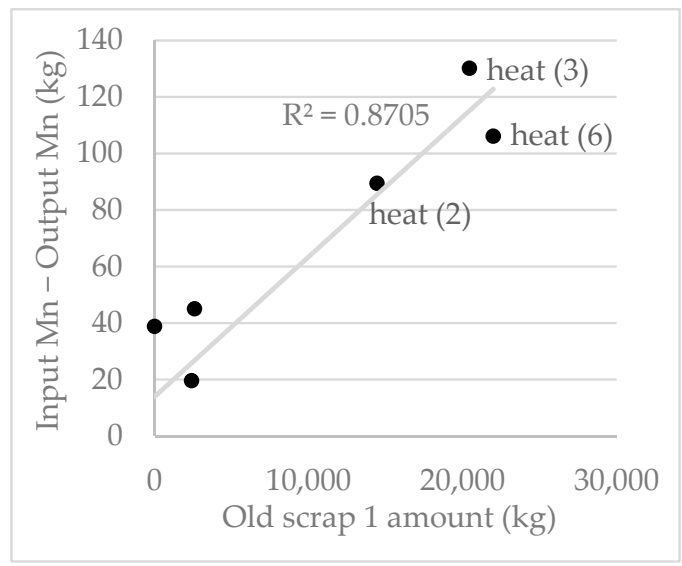

(c)

Figure 2. (a) Calculated slag mass based on the slag composition and $\mathrm{CaO}$ balance, as a function of the calculated values using RAWMATMIX ${ }^{\circledR}$ for the calibration heats $(1-8), R \approx 0.81$. (b) difference between estimated and calculated oxide amounts $\left(\mathrm{MnO}, \mathrm{MgO}, \mathrm{SiO}_{2}, \mathrm{Al}_{2} \mathrm{O}_{3}\right.$, and $\left.\mathrm{TiO}_{2}\right)$ versus differences between estimated and calculated slag amounts. (c) difference between input and output amounts of Mn versus Old scrap 1 amount.

$\lambda_{\mathrm{MgO}}$ is calculated using the average refractory wear and distribution ratios for all heats as well as using the individual calculated values for each heat. A comparison between $\lambda_{\mathrm{MgO}}$, calculated using slag analysis (Table 2 ) and $\lambda_{\mathrm{MgO}}$ calculated using calculated slag composition by RAWMATMIX ${ }^{\circledR}$ is shown for both approaches in Figure 3.

It can be seen that there is a better agreement when the individual values are applied, Figure $3 \mathrm{~b}$ $(R \approx 0.76)$ compared to the case using average values $(R \approx 0.37)$, Figure 3a. The standard deviation for the refractory wear is quite high, around 1.4 which is one reason for this discrepancy. Other sources causing a difference is the assumed concentration of $\mathrm{Al}$ and uncertainties in $\mathrm{Ti}$ and $\mathrm{Si}$ contents in scraps, since $\mathrm{MgO}^{e q}$ is a function of $\mathrm{Al}_{2} \mathrm{O}_{3}, \mathrm{TiO}_{2}$ and $\mathrm{SiO}_{2}$ contents in slag, as shown in the Appendix $\mathrm{B}$. The maximum error when the average values are used is around 0.57 , related to heat (2), which is a fairly high value.

\subsubsection{Dust}

The average calculated dust amount is approximately $21 \mathrm{~kg} / \mathrm{t}$, which is $7 \mathrm{~kg} / \mathrm{t}$ lower than the average value. The reason can be explained by the fact the value $28 \mathrm{~kg} / \mathrm{t}$ is a yearly average, which is not exactly representative of these specific heats. Moreover, uncertainties in Zn concentrations in scraps can affect this underestimation of dust amounts. 


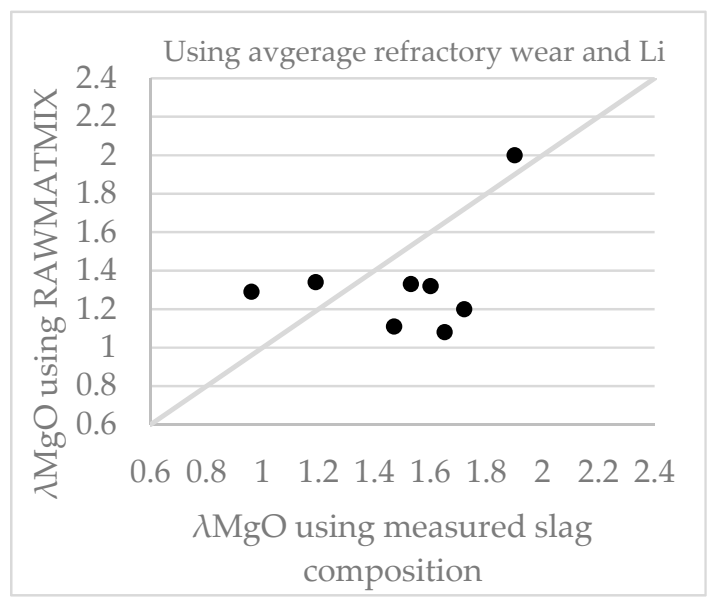

(a)

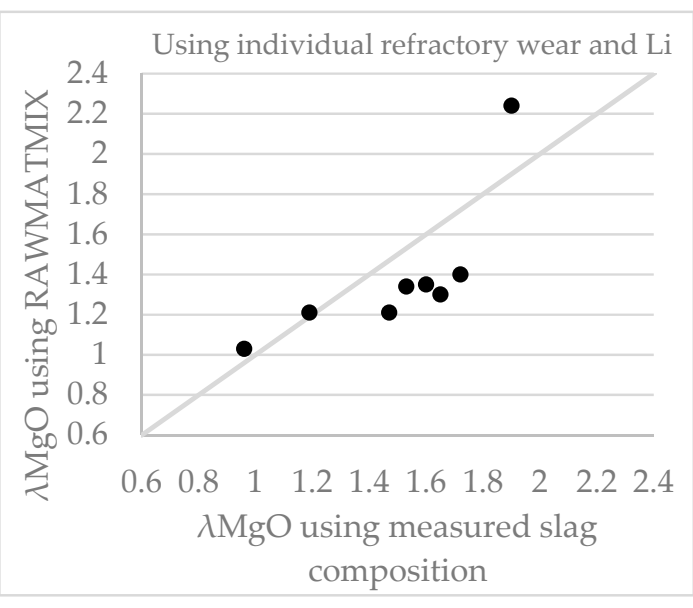

(b)

Figure 3. Calculated $\lambda \mathrm{MgO}$ by using slag analysis and $\lambda \mathrm{MgO}$ calculated values using RAWMATMIX ${ }^{\circledR}$ using (a) average values for refractory wear and distribution ratios, $R \approx 0.37$ and (b) individual values for refractory wear and distribution ratios, $R \approx 0.76$.

\subsubsection{Electricity}

The electricity input is calculated using the energy balance equations, namely Equations (14) to (20). The comparison between the actual electricity consumption and the calculated one for all heats is shown in Figure 4. A good agreement with a correlation coefficient $(R)$ of 0.94 is obtained. The differences are between $5-1712 \mathrm{kWh} /$ heat. This can be because of the use of the same values of heat losses for all heats, which in fact are different for each heat under production conditions. Other sources of errors include temperature measurements of the melt and the assumption of a hot heel temperature of $1600{ }^{\circ} \mathrm{C}$.

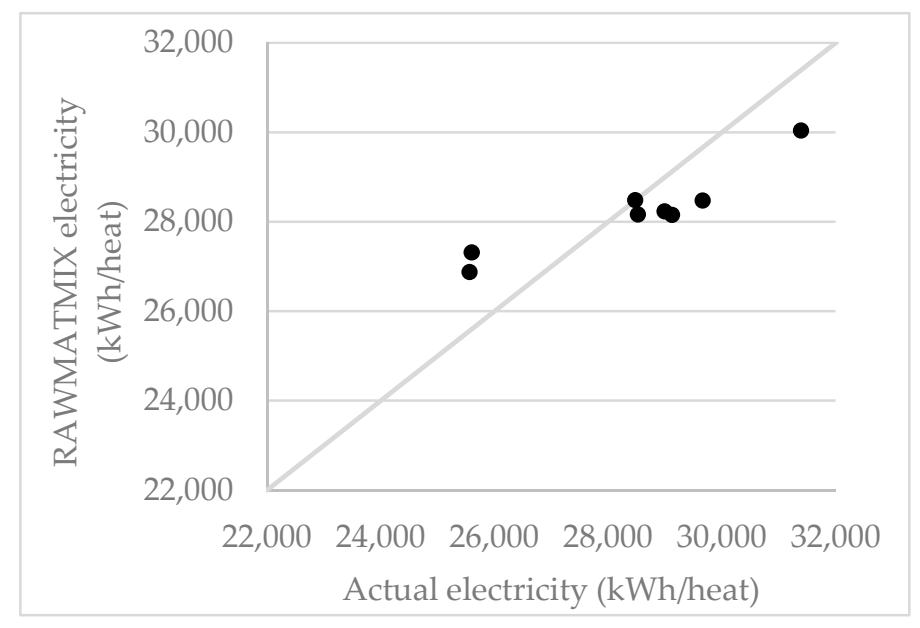

Figure 4. Comparison between the actual electricity consumption and electricity values calculated by $\operatorname{RAWMATMIX}^{\circledR}(\mathrm{kWh} /$ heat $), R \approx 0.94$.

\subsubsection{Melt Composition}

The results of the calculated concentrations of $\mathrm{P}, \mathrm{S}, \mathrm{Mn}, \mathrm{Cr}$, and $\mathrm{Cu}$ are compared to the measured values, as shown in Figure 5. The highest divergence is observed for $\mathrm{P}$ in heat (2) having an estimated $\lambda_{P}$ value equal to 0.34 , while an average $\lambda_{P}$ value equal to 0.78 is applied. When the calculation was done assuming $\lambda_{P}=0.34$ for this heat, a measured value of $0.008 \%$ for $P$ is reached. The differences between the measured and calculated values can mainly be explained by the uncertainties in chemical compositions and errors in measurements of the amounts of raw materials as well as the chemical 
compositions and amounts of melt and slag. For $\mathrm{S}$, a difference between measured and the calculated values are observed in heat (6). Heat (6) is mostly charged by Old scrap $1(42 \%)$, shown in Table A4 (Appendix A).

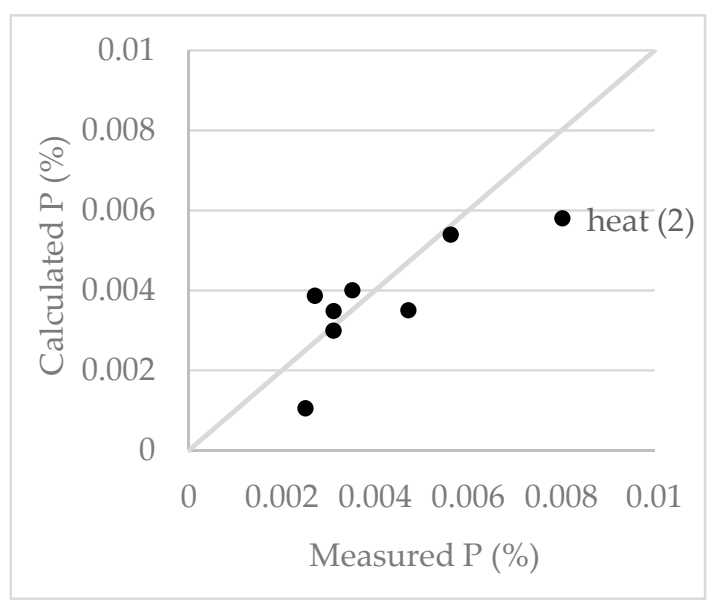

(a)

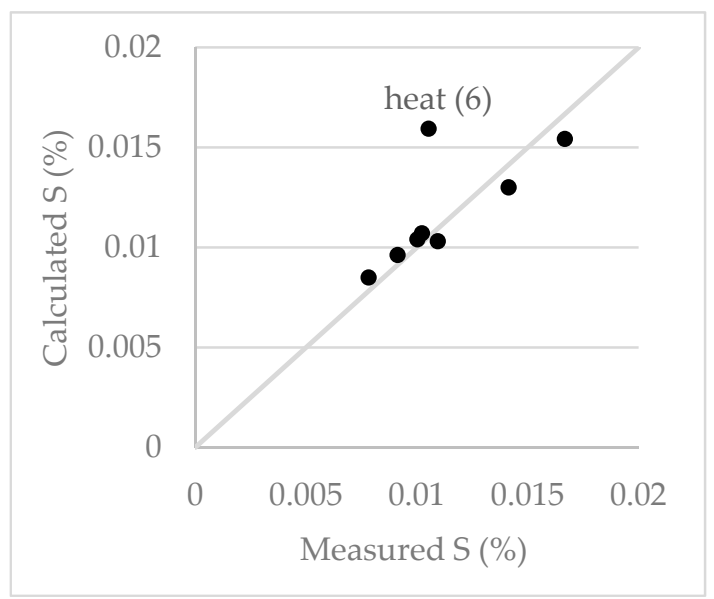

(c)

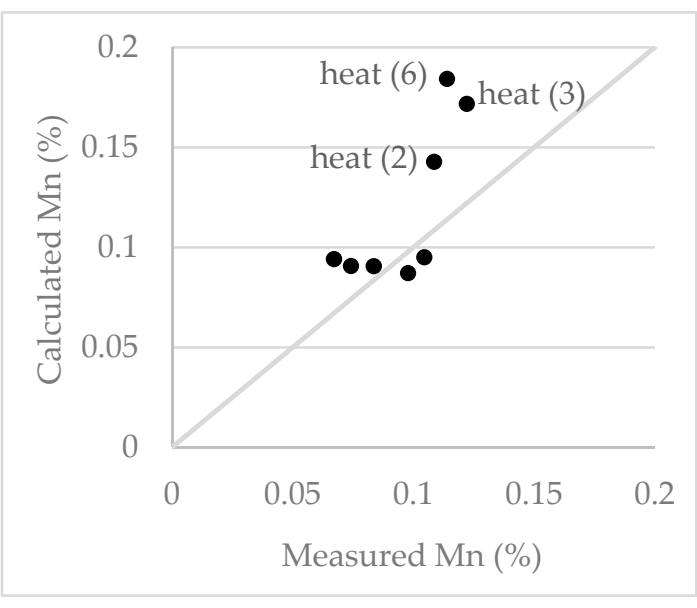

(b)

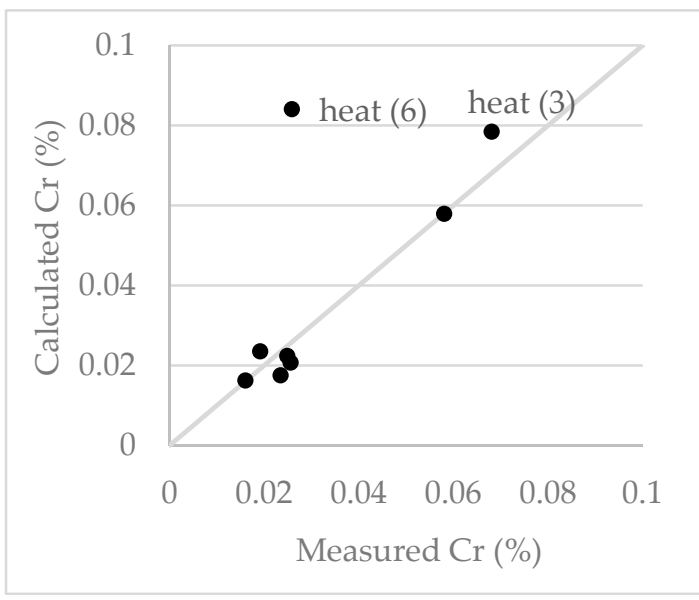

(d)

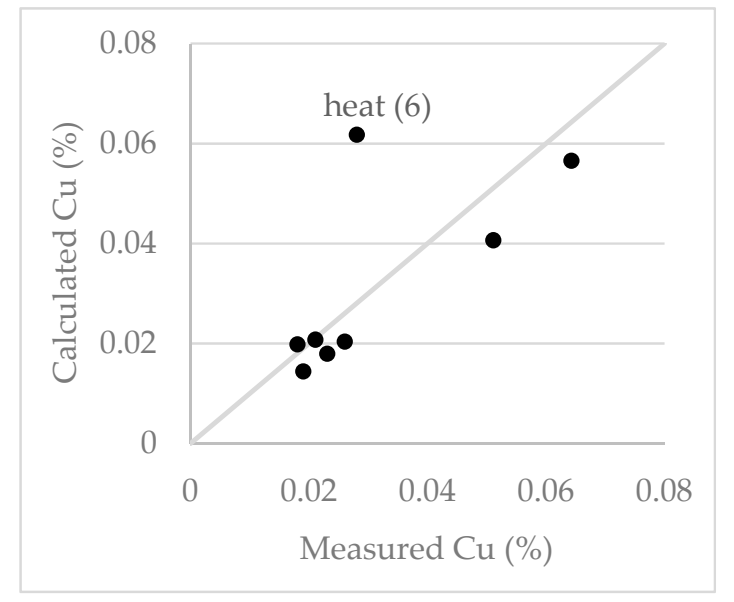

(e)

Figure 5. Comparison between the calculated and measured concentrations of (a) $\mathrm{P}$, (b) $\mathrm{Mn}$, (c) $\mathrm{S}$, (d) $\mathrm{Cr}$ and (e) $\mathrm{Cu}$ for the calibration heats (1-8). 
The uncertainties in the chemical compositions of these scraps can explain the difference. Besides, this heat is the only heat having sculls, and the average composition assumed for scull can contribute to this discrepancy. The high divergence between the measured and calculated results can also be seen in heat (6) for $\mathrm{Cr}, \mathrm{Mn}$, and $\mathrm{Cu}$. The correlation coefficients $(R)$ and the maximum absolute error $\left(E_{M a x}\right)$ between the measured and calculated values excluding heat (6) all heats are shown in Table 8 for $P$, $\mathrm{S}, \mathrm{Cr}, \mathrm{Mn}$, and $\mathrm{Cu}$. The correlation ratios for $\mathrm{S}, \mathrm{Cr}$, and $\mathrm{Cu}$ are quite high $(R \approx 0.98-0.99)$. However, the correlation coefficient for $\mathrm{Mn}$ is lower, $R \approx 0.75$. After heat (6), the highest differences for Mn are observed for heat (3) and heat (2) which were charged by $38 \%$ and $25 \%$ Old scrap 1 . These results strengthen the conclusion obtained by Figure $2 c$ that Old scrap 1 has a high uncertainty in Mn content.

Table 8. The correlation coefficient (R) for the concentration of $\mathrm{P}, \mathrm{S}, \mathrm{Mn}, \mathrm{Cr}$, and $\mathrm{Cu}$ for heats (1-8).

\begin{tabular}{cccccc}
\hline Element & $\mathbf{P}$ & $\mathbf{M n}$ & $\mathbf{S}$ & $\mathbf{C r}$ & $\mathbf{C u}$ \\
\hline$R$ & 0.82 & 0.75 & 0.99 & 0.98 & 0.98 \\
$E_{\text {Max }}$ & 0.0021 & 0.07 & 0.0006 & 0.061 & 0.032 \\
\hline
\end{tabular}

\subsection{Validation Results}

The maximum absolute error $\left( \pm E_{\text {Max }}\right)$ between the measured and calculated values for electricity in the calibration heats is applied to the calculated electricity for the validation heats. The comparison between these values and the measured ones is shown in Figure 6. The measured electricity consumptions lie in the intervals for all heats, which shows that the estimated error can be applied to the calculated results.

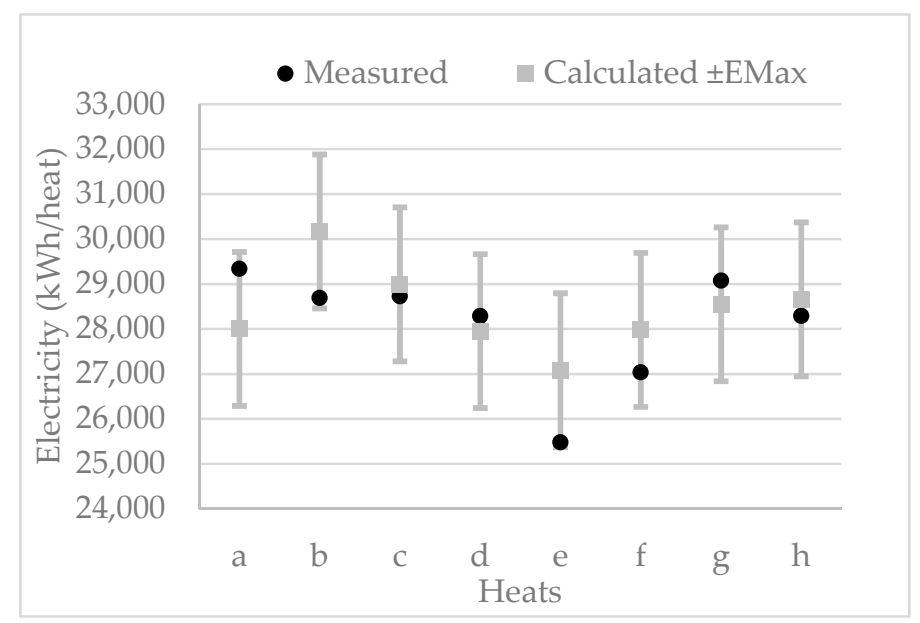

Figure 6. Comparison between the calculated $\pm E_{M a x}$ and measured electricity consumption for the validation heats $(\mathrm{a}-\mathrm{h})$.

The validation modeling is done for 8 heats, $(\mathrm{a}-\mathrm{h})$. The maximum absolute error $\left( \pm E_{\text {Max }}\right)$ between the measured and calculated values obtained for the calibration heats (excluding heat (6)) is applied to the calculated concentrations of $\mathrm{P}, \mathrm{Mn}, \mathrm{S}, \mathrm{Cr}$, and $\mathrm{Cu}$ for the validation results. These results are compared to the measured values in Figure 7. It can be seen that concentrations are outside the predicted intervals for Mn, Cr, S in heat (a) and for all the elements in heat (e). The differences in heat (e) are much higher (5-19 times) than those in heat (a). Heat (e) is charged by 45\% Old scrap 1, which is similar to heat (6) excluded from the maximum error calculation $\left(E_{M a x}\right)$. Thus, this is why heat (e) lies outside the confidence interval. Heat (a) is charged by $33 \%$ Old scrap 1, and it shows a lower difference between calculated and measured values. This strengthens the explanation that an overestimation (significant safety margin) of the elemental contents in the Old scrap 1 has caused this discrepancy. Therefore, the calculated error for each element can be applied to those heats which use smaller amounts of the Old scrap $1(<30 \%)$. 


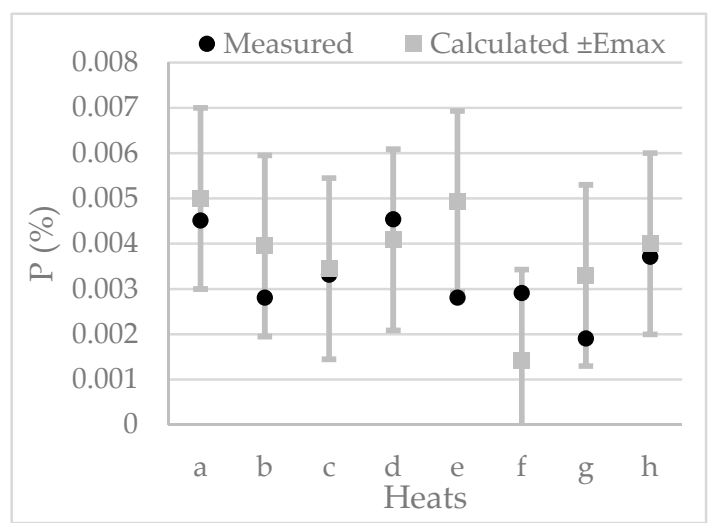

(a)

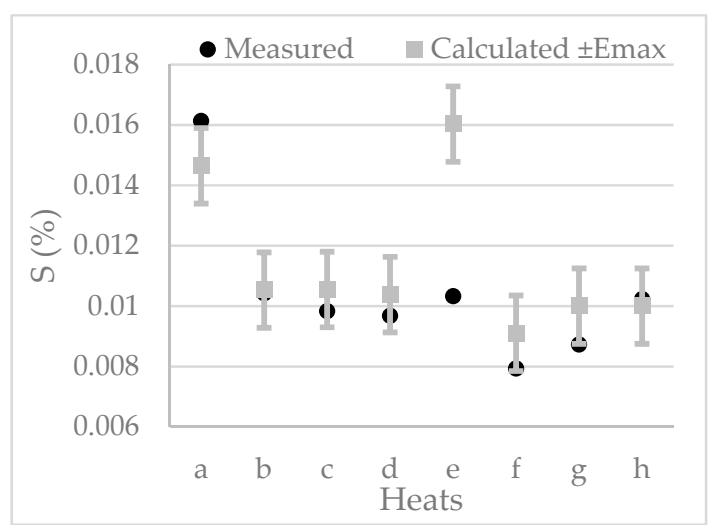

(c)

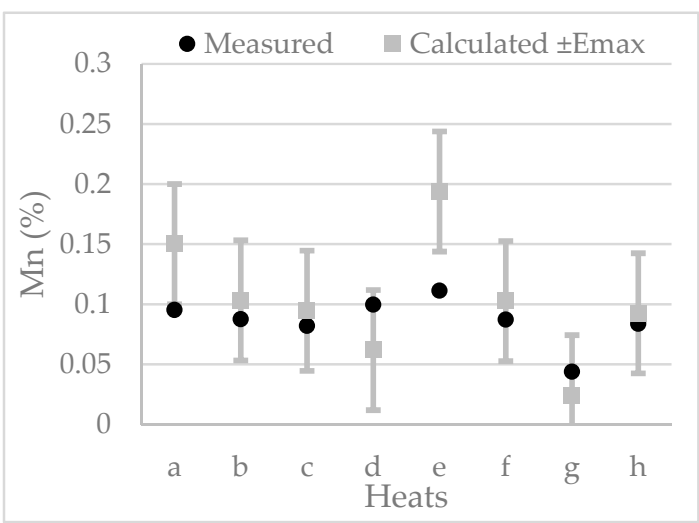

(b)

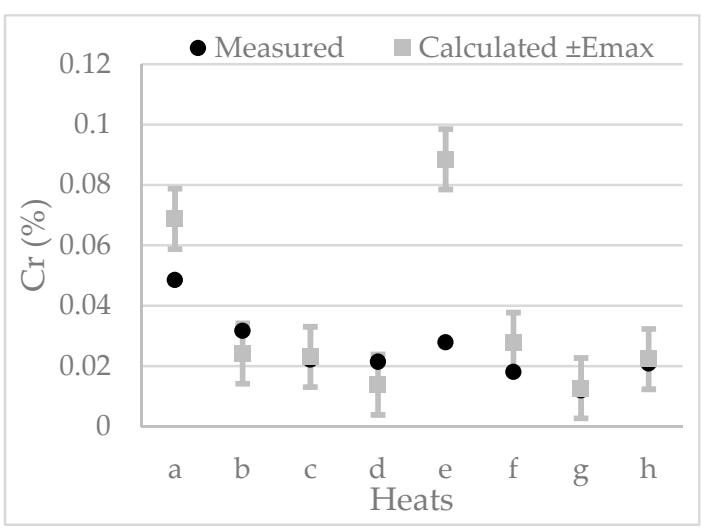

(d)

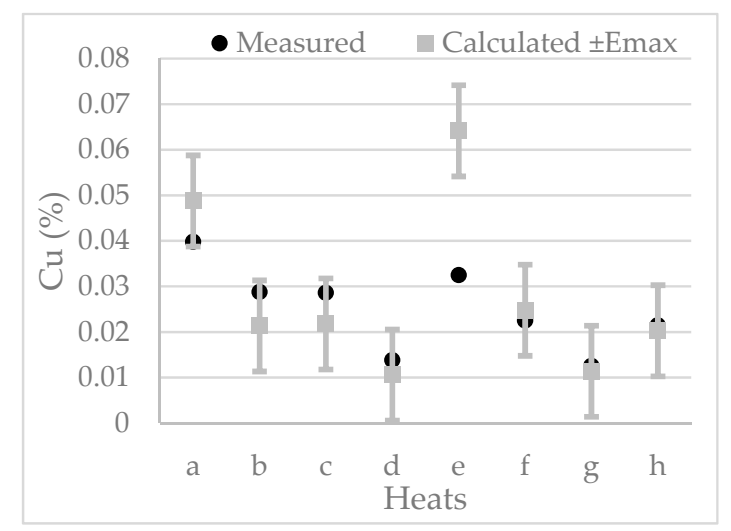

(e)

Figure 7. Comparison between the calculated $\pm E_{M a x}$ and measured concentrations of (a) $\mathrm{P},(\mathbf{b}) \mathrm{Mn}$, (c) $\mathrm{S}$, (d) $\mathrm{Cr}$ and (e) $\mathrm{Cu}$ for the validation heats $(\mathrm{a}-\mathrm{h})$.

\subsection{Model Application Results}

Figure 8 shows that increased amounts of charged HBI result in increased slag amounts by $34 \mathrm{~kg}$ per percent of HBI, which is due to the high amount of oxides in HBI. The degree of $\mathrm{MgO}$ saturation in the slag, $\lambda_{\mathrm{MgO}}$, decreases, so that cases $4-7$ result in $\lambda_{\mathrm{MgO}}$ values smaller than 1 . These results suggest that it is necessary to increase the amounts of slag formers containing $\mathrm{CaO}$ to lower the $\mathrm{MgO}$ saturation $\left(\% \mathrm{MgO}^{\text {sat }}\right)$ or/and increase the concentration of $\mathrm{MgO}$ in slag by increasing the dolomite addition. The high $\mathrm{MgO}$ saturation value is caused by an increased content of $\mathrm{SiO}_{2}$ in the slag due to the increased HBI amounts. If the maximum absolute error of 0.57 for $\lambda_{\mathrm{MgO}}$ is taken into account, there is a possibility that all cases are undersaturated or oversaturated. 


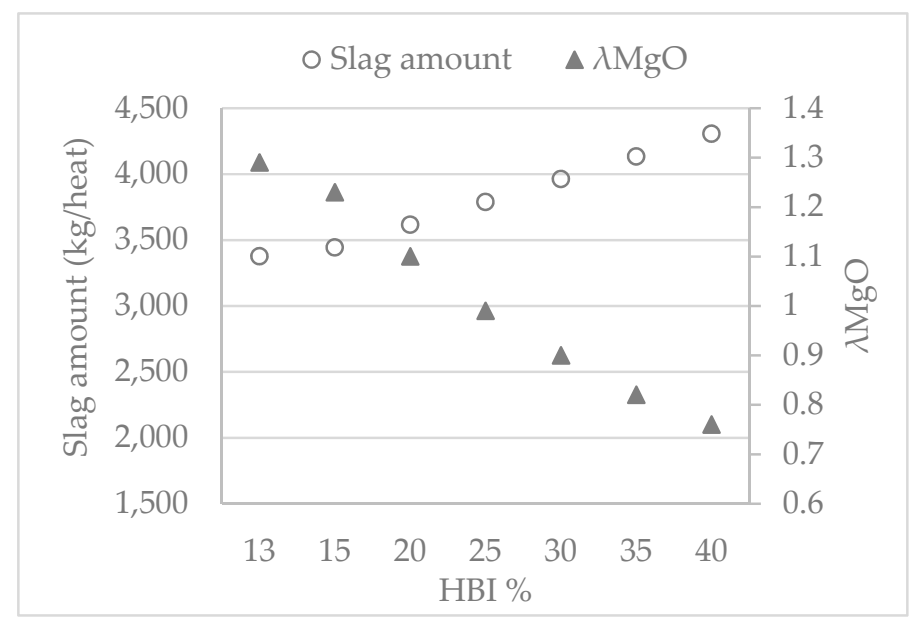

Figure 8. Variation of $\lambda_{\mathrm{MgO}}=\frac{\left(\% \mathrm{MgO}^{\text {slag }}\right)}{\left(\% \mathrm{MgO}^{\text {sat }}\right)}$ and slag amount versus the percentage of $\mathrm{HBI}$ in the total charged materials.

The required oxygen amount for metal oxidation (excluding oxygen for decarburization) decreases with increased HBI additions $\left(0.16 \mathrm{Nm}^{3} / \mathrm{t}\right.$ per each percent $\left.\mathrm{HBI}\right)$, as shown in Figure 9 . This change is due to the introduction of more oxygen which is present in the HBI, compared to scraps. This is mainly due to a reduction of $\mathrm{FeO}$ having a high content in $\mathrm{HBI}$, around 9\%. The required electricity amount increases by $35 \mathrm{kWh} / \mathrm{t}$, when the HBI amount is increased from $13 \%$ to $40 \%$. This corresponds to an increase of $1.29 \mathrm{kWh} / \mathrm{t}$ per each percent HBI, as is shown in Figure 9.

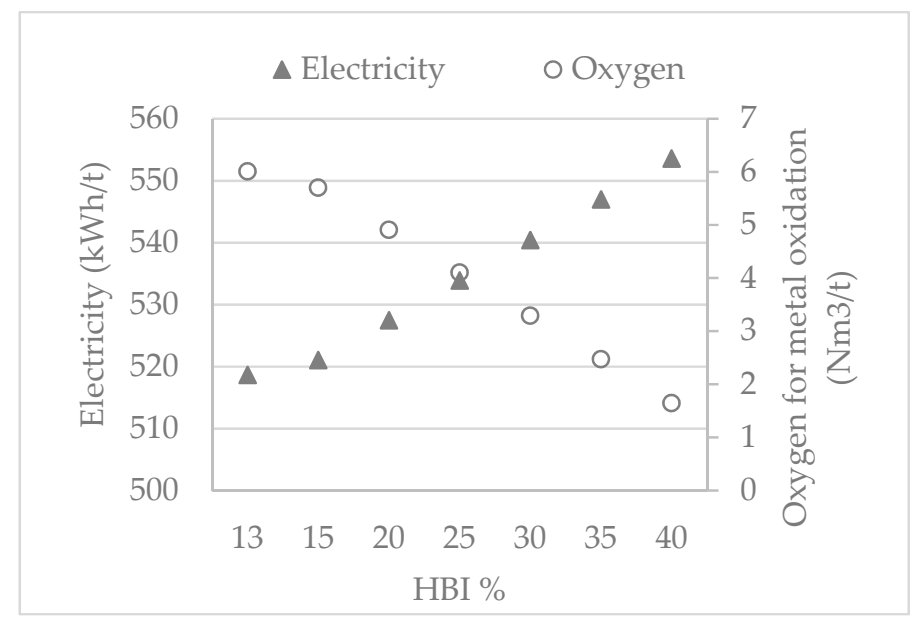

Figure 9. Electricity and oxygen consumption for metal oxidation versus the percentage of the charged HBI amount.

The effect of increasing the HBI content on the dilution of $\mathrm{Cu}, \mathrm{Cr}, \mathrm{P}, \mathrm{S}$, and $\mathrm{Mn}$ is shown in Figure 10. The concentration of $\mathrm{Mn}, \mathrm{Cr}$, and $\mathrm{Cu}$ decreased by $1.19 \%, 1.12 \%$ and $0.99 \%$ per addition of $1 \% \mathrm{HBI}$, respectively. This is due to a lack of these elements in HBI. The concentration of $\mathrm{P}$ and $\mathrm{S}$ increases by $4 \%$ and $0.84 \%$ per addition of $1 \% \mathrm{HBI}$, respectively. This is due to the relatively high contents of $\mathrm{P}$ and $\mathrm{S}(0.02 \%)$ in HBI. It should be noticed that the maximum errors for each element should be taken into account, as presented in Table 8 . 


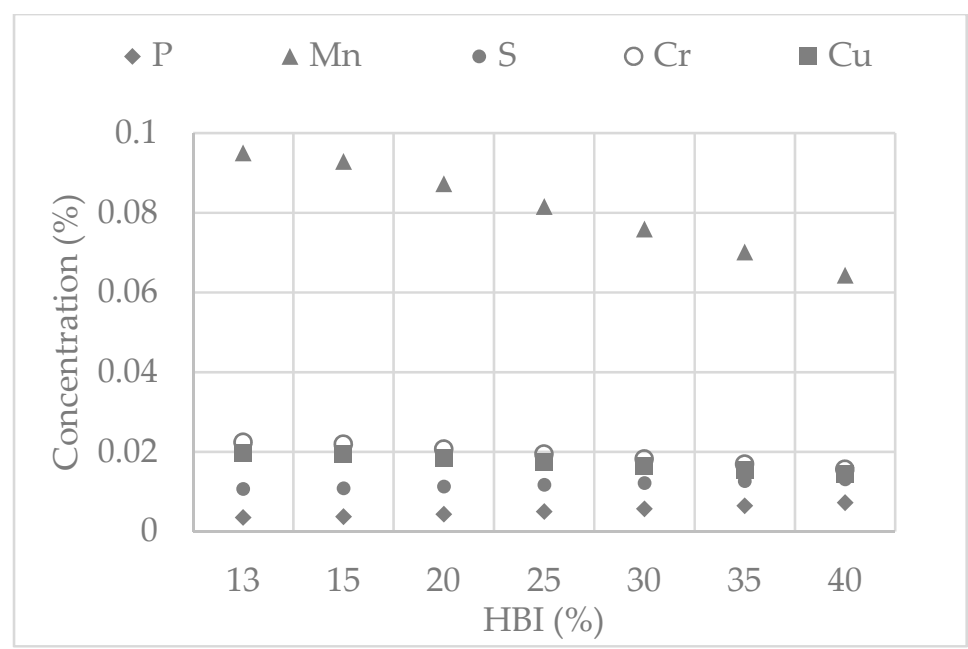

Figure 10. The calculated concentrations of $\mathrm{Cr}, \mathrm{Mn}, \mathrm{S}, \mathrm{Cu}$, and $\mathrm{P}$ in the final melt versus the percentage of the charged HBI amount.

\section{Adjustment of Slag Formers}

The amounts of slag formers are adjusted for cases $4-7$ for which the $\lambda_{\mathrm{MgO}}$ values were lower than 1 when the usual slag practice was applied. The target $\lambda_{\mathrm{MgO}}$ value is set to 1 , in order to reduce the refractory wear [18]. The target composition for $\mathrm{FeO}$ and $\mathrm{CaO}_{20}(\mathrm{CaO}$ content for a slag containing $20 \% \mathrm{FeO}$ ) in the slag are set to $22 \%$ and $40 \%$. The results of the new slag former additions and $\lambda_{\mathrm{MgO}}$ values are shown in Table 9. The number of slag increases for all cases $(133-804 \mathrm{~kg} / \mathrm{heat})$ due to the addition of higher amounts of lime for all cases and dolomite for case 5-7. The electricity consumption increases from 1-7 kWh/heat, which is due to the charging of higher lime amounts.

Table 9. Slag former adjustment and the resulted slag mass and $\lambda_{\mathrm{MgO}}$ for cases (4-7).

\begin{tabular}{ccccc}
\hline Case & $\mathbf{4}$ & $\mathbf{5}$ & $\mathbf{6}$ & $\mathbf{7}$ \\
\hline HBI (\%) & 25 & 30 & 35 & 40 \\
lime (kg) & 1168 & 1228 & 1288 & 1347 \\
Dolomite $(\mathrm{kg})$ & 594 & 716 & 838 & 961 \\
slag mass $(\mathrm{kg})$ & 3921 & 4317 & 4713 & 5109 \\
$\lambda_{\mathrm{MgO}}$ & 1 & 1 & 1 & 1 \\
\hline
\end{tabular}

\section{Conclusions}

A static mass and energy balance model combined by a $\mathrm{MgO}$ saturation slag model that can be used in electric arc furnaces has been developed. The model is applicable in raw material selection and can be used to predict energy consumption, element concentration in melt and slag properties. Initially, data for a number of heats from a production plant was used to calibrate model parameters for that furnace, namely the distribution ratios and dust factors. The maximum absolute errors between the calculated and actual parameters (melt analysis, electricity, slag amount and $\mathrm{MgO}$ saturation) are estimated. Then, the influence of HBI addition on energy and oxygen requirements as well as the slag were studied as an application of the model for process evaluations. The calculations were made where the HBI content was increased from $13 \%$ to $40 \%$, while the remaining raw part of the charged material was scrap. The results show that an addition $1 \%$ of $\mathrm{HBI}$ results in 
1. an increased electricity demand of $1.29 \mathrm{kWh} / \mathrm{t}$

2. a decreased amount of $0.16 \mathrm{Nm}^{3} / \mathrm{t}$ of oxygen for metal oxidation

3. an increased amount of slag by $34 \mathrm{~kg}$

Author Contributions: Methodology, N.A., R.G.; Software development, N.A. Supervision, R.G. and P.G.J.; Writing - original draft, N.A.; Writing - review \& editing, R.G. and P.G.J. All authors have read and agreed to the published version of the manuscript.

Funding: This research is founded by Stiftelsen Axel Hultgrens Fond and Kobolde \& Partners AB in Sweden.

Acknowledgments: The authors wish to thank Fredrik Cederholm, now at Uddeholms AB, for invaluable helps in process data collection and Hamid Doostmohammadi, from Royal Institute of Technology (KTH) and Roger Selin for useful discussions.

Conflicts of Interest: The authors declare no conflict of interest.

\section{Appendix A}

Table A1. Thermodynamic data for metallic elements and cementite in the melt [17].

\begin{tabular}{ccccccc}
\hline Element & $\begin{array}{c}\text { Molar Mass } \\
\mathbf{( g / m o l})\end{array}$ & $\begin{array}{c}\mathbf{H}^{\mathbf{2 9 8}} \\
\mathbf{( k J / m o l})\end{array}$ & $\begin{array}{c}\mathbf{H}^{\mathbf{1 7 0 0}} \\
\mathbf{( k J / m o l})\end{array}$ & $\begin{array}{c}\mathbf{H}^{\mathbf{m i x}} \\
\mathbf{( k J / m o l})\end{array}$ & $\begin{array}{c}\mathbf{C}_{\mathbf{p}} \mathbf{1 7 0 0} \\
\mathbf{( J / m o l})\end{array}$ & $\begin{array}{c}\mathbf{C}_{\mathbf{p}} \mathbf{2 9 8} \\
(\mathbf{J} / \mathbf{m o l})\end{array}$ \\
\hline $\mathrm{C}$ & 12.01 & 0.00 & 28.03 & 22.59 & 24.40 & 8.53 \\
$\mathrm{Si}$ & 28.09 & 0.00 & 86.67 & -131.50 & 27.22 & 20 \\
$\mathrm{Mn}$ & 54.94 & 0.00 & 73.24 & 4.08 & 46.06 & 26.3 \\
$\mathrm{P}$ & 30.97 & 71.90 & 97.35 & -122.17 & 18.85 & 23.84 \\
$\mathrm{~S}$ & 32.06 & 64.38 & 89.93 & -135.06 & 18.83 & 22.6 \\
$\mathrm{Cr}$ & 52.00 & 0.00 & 46.55 & 19.25 & 47.15 & 23.3 \\
$\mathrm{Ni}$ & 58.69 & 0.00 & 63.83 & -20.92 & 43.13 & 26.1 \\
$\mathrm{Mo}$ & 95.94 & 0.00 & 39.87 & 27.61 & 35.12 & 24.1 \\
$\mathrm{Ti}$ & 47.87 & 0.00 & 46.54 & -31.13 & 25.69 & 25 \\
$\mathrm{Cu}$ & 63.55 & 0.00 & 53.34 & 33.47 & 31.41 & 24.43 \\
$\mathrm{~V}$ & 50.94 & 0.00 & 65.38 & -42.26 & 41.88 & 24.9 \\
$\mathrm{Fe}$ & 55.85 & 0.00 & 67.98 & 0.00 & 46.06 & 25.1 \\
\hline
\end{tabular}

Table A2. Thermodynamic data for metal oxides [17].

\begin{tabular}{cccccc}
\hline Element & Mol Mass (g/mol) & $\mathbf{H}^{\mathbf{2 9 8}} \mathbf{( k J / m o l )}$ & $\mathbf{H}^{\mathbf{1 7 0 0}} \mathbf{( \mathbf { k J } / \mathbf { m o l } )}$ & $\left.\mathbf{C}_{\mathbf{p}}{ }^{\mathbf{1 7 0 0}} \mathbf{( J / m o l}\right)$ & $\mathbf{C}_{\mathbf{p}}{ }^{\mathbf{2 9 8}}(\mathbf{J} / \mathbf{m o l})$ \\
\hline $\mathrm{SiO}_{2}$ & 60.09 & -909.13 & -814.07 & 73.96 & 73.96 \\
$\mathrm{Al}_{2} \mathrm{O}_{3}$ & 101.96 & -1676.72 & -1507.73 & 136.74 & 136.73 \\
$\mathrm{FeO}$ & 71.85 & -261.01 & -160.23 & 68.20 & 68.2 \\
$\mathrm{MnO}$ & 70.94 & -385.26 & -309.68 & 61.65 & 61.65 \\
$\mathrm{CaO}$ & 56.08 & -634.84 & -560.81 & 58.07 & 58.07 \\
$\mathrm{MgO}$ & 40.30 & -601.76 & -531.80 & 54.68 & 54.68 \\
$\mathrm{P}_{2} \mathrm{O}_{5}$ & 141.94 & -1506.24 & -1247.71 & 162.50 & 162.5 \\
$\mathrm{VO}_{2}$ & 181.88 & -1559.05 & -1242.72 & 190.95 & 74.68 \\
$\mathrm{TiO}_{2}$ & 79.90 & -945.56 & -844.20 & 84.23 & 84.23 \\
$\mathrm{Cr}_{2} \mathrm{O}_{3}$ & 151.97 & -1130.65 & -954.60 & 67.53 & 67.52 \\
$\mathrm{NiO}^{70}$ & 74.70 & -240.79 & -162.14 & 62.90 & 62.9 \\
\hline
\end{tabular}


Table A3. The amount of materials (kg) used in the calibration heats (1-8) and validation heats (a-h).

\begin{tabular}{|c|c|c|c|c|c|c|c|c|}
\hline Heat & 1 & 2 & 3 & 4 & 5 & 6 & 7 & 8 \\
\hline HBI & 6900 & 6700 & 7300 & 8500 & 0 & 6950 & 6600 & 6700 \\
\hline Pig Iron 1 & 1100 & 1050 & 1600 & 1250 & 0 & 1200 & 1000 & 1550 \\
\hline Pig Iron 2 & 3050 & 3450 & 3700 & 3150 & 0 & 3350 & 3400 & 3300 \\
\hline Old scrap 1 & 2400 & 14,450 & 20,450 & 1150 & 0 & 22,000 & 0 & 2600 \\
\hline Old scrap 2 & 0 & 6900 & 10,100 & 0 & 0 & 11,000 & 0 & 0 \\
\hline Old scrap 3 & 3250 & 0 & 0 & 4450 & 0 & 0 & 3950 & 3350 \\
\hline New scrap 1 & 12,400 & 9300 & 0 & 10,100 & 18,600 & 0 & 12,400 & 8150 \\
\hline New scrap 2 & 12,400 & 11,250 & 1350 & 10,150 & 12,100 & 0 & 10,500 & 9850 \\
\hline New scrap 3 & 11,200 & 0 & 0 & 9450 & 18,800 & 0 & 12,850 & 13,950 \\
\hline Return 1 & 0 & 4250 & 6750 & 3650 & 0 & 2500 & 1500 & 2550 \\
\hline Return 2 & 0 & 0 & 0 & 0 & 3000 & 0 & 0 & 0 \\
\hline Sculls & 0 & 0 & 0 & 0 & 0 & 1850 & 0 & 0 \\
\hline Return 3 & 0 & 0 & 2050 & 1500 & 0 & 3300 & 0 & 0 \\
\hline Hot heel type & 1 & - & 2 & 1 & 3 & 2 & 1 & 1 \\
\hline Coke & 870 & 794 & 799 & 725 & 806 & 799 & 718 & 722 \\
\hline Lime & 1000 & 1000 & 1000 & 1000 & 1000 & 1000 & 1000 & 1000 \\
\hline Dolomite & 650 & 650 & 600 & 700 & 600 & 800 & 500 & 600 \\
\hline Heat & $\mathbf{a}$ & b & c & d & e & f & g & h \\
\hline HBI & 7200 & 8300 & 8800 & 9300 & 6400 & 0 & 10,250 & 6750 \\
\hline Pig Iron 1 & 900 & 1000 & 1000 & 1800 & 800 & 0 & 3000 & 1200 \\
\hline Pig Iron 2 & 2950 & 2900 & 2700 & 3950 & 3300 & 0 & 4250 & 3100 \\
\hline Old scrap 1 & 17,500 & 2050 & 2450 & 0 & 23,450 & 2100 & 0 & 2150 \\
\hline Old scrap 2 & 6450 & 0 & 0 & 0 & 11,500 & 0 & 0 & 0 \\
\hline Old scrap 3 & 0 & 4900 & 4500 & 0 & 0 & 3500 & 0 & 3350 \\
\hline New scrap 1 & 5350 & 9600 & 9300 & 12,450 & 0 & 8400 & 0 & 9100 \\
\hline New scrap 2 & 3100 & 11,400 & 12,450 & 10,650 & 0 & 23,100 & 32,550 & 10,500 \\
\hline New scrap 3 & 0 & 12,450 & 9950 & 10,850 & 0 & 13,300 & 0 & 13,100 \\
\hline Return 1 & 8750 & 3550 & 2050 & 0 & 3300 & 1550 & 2350 & 2700 \\
\hline Return 2 & 0 & 0 & 0 & 1700 & 0 & 0 & 0 & 0 \\
\hline Sculls & 950 & 0 & 0 & 1950 & 2200 & 0 & 0 & 0 \\
\hline Return 3 & 0 & 1900 & 1150 & 0 & 1500 & 0 & 0 & 0 \\
\hline hot heel & 5000 & 0 & 5000 & 5000 & 5000 & 5000 & 5000 & 5000 \\
\hline Hot heel type & 2 & 2 & 1 & 3 & 3 & 1 & 1 & 1 \\
\hline Coke & 799 & 794 & 724 & 800 & 797 & 723 & 719 & 723 \\
\hline Lime & 1000 & 1000 & 1000 & 1000 & 1000 & 1000 & 1000 & 1000 \\
\hline Dolomite & 750 & 600 & 600 & 550 & 550 & 700 & 600 & 600 \\
\hline
\end{tabular}

Table A4. The chemical compositions of the raw materials, sculls and hot heel in wt. \%. The remaining composition for $\mathrm{HBI}$ contains other oxides, $\mathrm{SiO}_{2}, \mathrm{P}_{2} \mathrm{O}_{5}, \mathrm{Al}_{2} \mathrm{O}_{3}, \mathrm{CaO}, \mathrm{MgO}$ and $\mathrm{TiO}_{2}$.

\begin{tabular}{cccccccccccc}
\hline Input Material & $\mathbf{F e}$ & $\mathbf{F e O}$ & $\mathbf{S i}$ & $\mathbf{P b}$ & $\mathbf{A s}$ & $\mathbf{C}$ & $\mathbf{S n}$ & $\mathbf{C a}$ & $\mathbf{T i}$ & $\mathbf{C u}$ & $\mathbf{M o}$ \\
\hline HBI & 83.964 & 9 & 0.005 & 0 & 0 & 1 & 0 & 0 & 0 & 0.0014 & 0 \\
Pig Iron 1 & 95.007 & 0 & 0.15 & 0 & 0 & 4.25 & 0 & 0 & 0.005 & 0 & 0 \\
Pig Iron 2 & 94.157 & 0 & 1 & 0 & 0 & 4.25 & 0 & 0 & 0.005 & 0 & 0 \\
Old scrap 1 & 98.022 & 0 & 0.3 & 0 & 0.001 & 0.4 & 0.01 & 0 & 0.001 & 0.1 & 0.02 \\
Old scrap 2 & 98.717 & 0 & 0.02 & 0 & 0 & 0.05 & 0.005 & 0 & 0.001 & 0.1 & 0.04 \\
Old scrap 3 & 97.07 & 0 & 0.35 & 0 & 0 & 0.05 & 0 & 0 & 0 & 0.1 & 0 \\
New scrap 1 & 98.586 & 0 & 0.01 & 0.009 & 0 & 0.02 & 0.001 & 0.0015 & 0.002 & 0.015 & 0.004 \\
New scrap 2 & 98.786 & 0 & 0.01 & 0.009 & 0 & 0.02 & 0.001 & 0.0015 & 0.002 & 0.015 & 0.004 \\
News crap 3 & 98.586 & 0 & 0.01 & 0.009 & 0 & 0.02 & 0.001 & 0.0015 & 0.002 & 0.015 & 0.004 \\
Return 1 & 97.619 & 2 & 0.002 & 0 & 0 & 0.3 & 0 & 0 & 0.001 & 0.03 & 0 \\
Return 2 & 98.675 & 0 & 0 & 0 & 0 & 0.4 & 0 & 0 & 0 & 0 & 0.84 \\
Sculls & 98.877 & 0 & 0.002 & 0.011 & 0 & 0.399 & 0.003 & 0.001 & 0.001 & 0.061 & 0.016 \\
Return 3 & 97.619 & 2 & 0.002 & 0 & 0 & 0.3 & 0 & 0 & 0.001 & 0.03 & 0 \\
Hot heel type 1 & 99.494 & 0 & 0.0015 & 0 & 0.006 & 0.3 & 0 & 0 & 0.0015 & 0.022 & 0.0085 \\
Hot heel type 2 & 99.373 & 0 & 0.001 & 0.001 & 0 & 0.3 & 0.0017 & 0 & 0.001 & 0.048 & 0.016 \\
Hot heel type 3 & 99.561 & 0 & 0.001 & 0.006 & 0 & 0.2 & 0.001 & 0 & 0.002 & 0.019 & 0.028 \\
\hline
\end{tabular}


Table A4. Cont.

\begin{tabular}{cccccccccccc}
\hline Input Material & $\mathbf{M n}$ & $\mathbf{W}$ & $\mathbf{V}$ & $\mathbf{C o}$ & $\mathbf{P}$ & $\mathbf{N i}$ & $\mathbf{S}$ & $\mathbf{C r}$ & $\mathbf{Z n}$ & $\mathbf{N b}$ & $\mathbf{A l}$ \\
\hline HBI & 0 & 0 & 0 & 0 & 0.02 & 0 & 0.02 & 0 & 0 & 0 & 0 \\
Pig Iron 1 & 0.013 & 0 & 0.015 & 0 & 0.029 & 0 & 0.006 & 0.025 & 0 & 0 & 0 \\
Pig Iron 2 & 0.013 & 0 & 0.015 & 0 & 0.029 & 0 & 0.006 & 0.025 & 0 & 0 & 0 \\
Old Scrap 1 & 0.8 & 0 & 0.001 & 0 & 0.02 & 0.1 & 0.025 & 0.2 & 0 & 0 & 0 \\
Old Scrap 2 & 0.8 & 0 & 0.001 & 0.001 & 0.005 & 0.15 & 0.01 & 0.1 & 0 & 0 & 0 \\
Old Scrap 3 & 1.2 & 0 & 0 & 0 & 0.02 & 0.1 & 0.01 & 0.1 & 1 & 0 & 0 \\
New Scrap 1 & 0.3 & 0.001 & 0.001 & 0 & 0.005 & 0.015 & 0.007 & 0.02 & 1 & 0.003 & 0 \\
New Scrap 2 & 0.1 & 0.001 & 0.001 & 0 & 0.005 & 0.015 & 0.007 & 0.02 & 1 & 0.003 & 0 \\
New Scrap 3 & 0.3 & 0.001 & 0.001 & 0 & 0.005 & 0.015 & 0.007 & 0.02 & 1 & 0.003 & 0 \\
Return 1 & 0.01 & 0 & 0.005 & 0 & 0.01 & 0.005 & 0.013 & 0.002 & 0 & 0 & 0.003 \\
Return 2 & 0.08 & 0 & 0 & 0 & 0.005 & 0 & 0 & 0 & 0 & 0 & 0 \\
Sculls & 0.13 & 0.004 & 0.001 & 0 & 0.006 & 0.046 & 0.014 & 0.066 & 0 & 0.004 & 0.03 \\
Return 3 & 0.01 & 0 & 0.005 & 0 & 0.01 & 0.005 & 0.013 & 0.002 & 0 & 0 & 0.003 \\
Hot heel 1 & 0.01 & 0 & 0.005 & 0 & 0.01 & 0.005 & 0.013 & 0.002 & 0 & 0 & 0.03 \\
Hot heel 2 & 0.115 & 0.002 & 0.001 & 0 & 0.006 & 0.036 & 0.014 & 0.051 & 0 & 0.0035 & 0.03 \\
Hot heel 3 & 0.098 & 0.001 & 0.001 & 0 & 0.0025 & 0.022 & 0.008 & 0.016 & & 0.0035 & 0.03 \\
\hline
\end{tabular}

\section{Appendix B}

See [18],

$$
\begin{aligned}
& \log L_{V}^{e q}=\log L_{V}^{r e f}+0.0395\left(\frac{C_{V O_{2}}}{1.6282}\right)-0.00273\left(\frac{C_{V O_{2}}}{1.6282}\right)^{2}-2.8024+\frac{5180}{T} \\
& \log L_{P}^{e q}=\log L_{P}^{r e f}+\log \left(\frac{1}{1.82}\left(1.6+\sqrt{1.28+\frac{P_{2} O_{5}}{2.2914}-1.6 \sqrt{0.64+\frac{P_{2} \mathrm{O}_{5}}{2.2914}}}\right)\right) \\
& -0.00129 \frac{\mathrm{C}_{\mathrm{Al}_{2} \mathrm{O}_{3}}}{\mathrm{C}_{\mathrm{SiO}_{2}}+\mathrm{C}_{\mathrm{Al}_{2} \mathrm{O}_{3}}+\mathrm{C}_{\mathrm{TiO}_{2}}+\mathrm{C}_{\mathrm{VO}_{2}}+\mathrm{C}_{\mathrm{P}_{2} \mathrm{O}_{5}}} \\
& -0.00098 \frac{\mathrm{C}_{\mathrm{TiO}_{2}}}{\mathrm{C}_{\mathrm{SiO}_{2}}+\mathrm{C}_{\mathrm{Al}_{2} \mathrm{O}_{3}}+\mathrm{C}_{\mathrm{TiO}_{2}}+\mathrm{C}_{\mathrm{VO}_{2}}+\mathrm{C}_{\mathrm{P}_{2} \mathrm{O}_{5}}} \\
& -0.00026 \frac{\mathrm{C}_{\mathrm{VO}_{2}}}{\mathrm{C}_{\mathrm{SiO}_{2}}+\mathrm{C}_{\mathrm{Al}_{2} \mathrm{O}_{3}} \mathrm{C}_{\mathrm{TiO}_{2}}+\mathrm{C}_{\mathrm{VO}_{2}}+\mathrm{C}_{\mathrm{P}_{2} \mathrm{O}}}-6.909+\frac{12940}{\mathrm{~T}}
\end{aligned}
$$

$$
\mathrm{MgO}^{e q}=\mathrm{MgO}^{r e f}
$$

$$
\begin{aligned}
& -\left(0.00615 \frac{\mathrm{C}_{\mathrm{Al}_{2} \mathrm{O}_{3}}}{\mathrm{C}_{\mathrm{CiO}_{2}}+\mathrm{C}_{\mathrm{Al}_{2} \mathrm{O}_{3}}+\mathrm{C}_{\mathrm{TiO}_{2}}+\mathrm{C}_{\mathrm{VO}_{2}}+\mathrm{C}_{\mathrm{P}_{2} \mathrm{O}_{5}}}\right.
\end{aligned}
$$

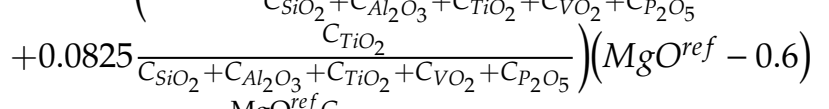

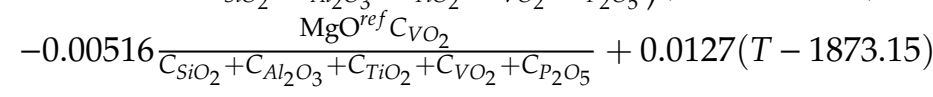

$L_{V}^{r e f}, L_{P}^{r e f}$ and $\mathrm{MgO}^{r e f}$ are computed from $\mathrm{LP}, \mathrm{LV}$ and $\mathrm{MgO}$ iso-solubility curves.

\section{References}

1. Toulouevski, Y.N.; Zinurov, I.Y. Innovation in Electric Arc Furnaces; Springer: Berlin/Heidelberg, Germany, 2010; pp. 1-22.

2. Rathaba, P.L.; Craig, I.K.; Pistorius, P.C. Influence of Oxyfuel Burner Subsystem on the EAF Process. IFAC Autom. Min. Miner. Met. Process. 2004, 37, 215-220. [CrossRef]

3. Madias, J. Electric Furnace Steelmaking. In Treatise in Process Metallurgy; Elsevier: Oxford, UK, 2014; Volume 3, pp. 271-272.

4. Morris, A.E.; Fine, H.A.; Geiger, G. Handbook on Material and Energy Balance Calculations in Material Processing; John Willey \& Sons: Hoboken, NJ, USA, 2011; p. 582.

5. Hasanbeigi, A.; Price, L.K.; McKane, A.T. The State-of-the-Art Clean Technologies (SOACT) for Steelmaking Handbook. Available online: https://www.jisf.or.jp/business/ondanka/eco/docs/SOACT-Handbook-2ndEdition.pdf (accessed on 4 February 2020). 
6. Von Starck, A.; Mühlbauer, A.; Kramer, C. Handbook of Thermoprocessing Technologies; Vulkan-Verlag GmbH: Essen, Germany, 2005; p. 298.

7. Alaneddine, S.; Bowman, B. Particularities of Melting DRI in AC and Dc arc furnaces. Arch. Metall. Mater. 2008, 53, 411-417.

8. Du, C.; Zhu, M.; Sun, L.; Dong, S. Metallurgical Characteristics and Effectiveness of Metallic Heats in Electric Arc Furnace. Asia Pac. J. Chem. Eng. 2006, 14, 353-362.

9. Morales, R.D.; Ruben Lule, G.; Lopez, F.; Camacho, J.; Romero, J.A. The Slag Foaming Practice in EAF and its influence on the steelmaking Shop Productivity. ISIJ Int. 1995, 35, 1054-1062. [CrossRef]

10. Kirschen, M.; Badr, K.; Cappel, J. Chemical Energy and Bottom Stirring Systems-Cost Effective Solutions for a Better Performing EAF. Int. J. ISSI 2009, 6, 1-8.

11. Bekker, J.G.; Craig, I.K.; Pistorius, P.C. Modeling and Simulation of an Electric Arc Furnace, Furnace. ISIJ Int. 1999, 39, 23-32. [CrossRef]

12. MacRosty, R.D.M.; Swartz, C.L.E. Dynamic Modeling of an Industrial Electric Arc Furnace. Ind. Eng. Chem. Res. 2005, 44, 8067-8083. [CrossRef]

13. Logar, V.; Dovžan, D.; Škrjanc, I. Modeling and Validation of an Electric Arc Furnace: Part 1, Heat and Mass Transfer. ISIJ Int. 2012, 52, 402-412. [CrossRef]

14. Hay, T.; Reimann, A.; Echterhof, T. Improving the Modelling of slag and Steel Bath Chemistry in an Electric Arc Furnace Process Model. Metall. Mater. Trans. B 2019, 50, 2377-2388. [CrossRef]

15. Kirschen, M.; Badr, K.; Pfeifer, H. Influence of Direct Reduced Iron on the Energy Balance of the Electric Arc Furnace in Steel Industry. Energy 2011, 36, 6146-6155. [CrossRef]

16. Andersson, A. A Study on Selected Hot-Metal and Slag Components for Improved Blast Furnace Control. Licentiate Thesis, Royal Institute of Technology, Stockholm, Sweden, 2003.

17. Barin, I.; Knacke, O.; Kubaschewski, O. Thermochemical Properties of Inorganic Substances; Springer: Berlin/Heidelberg, Germany, 1973.

18. Selin, R. The Role of Phosphorus, Vanadium and Slag Forming Oxides in Direct Reduction Based Steelmaking. Ph.D. Thesis, Royal Institute of Technology, Stockholm, Sweden, 1987.

(C) 2020 by the authors. Licensee MDPI, Basel, Switzerland. This article is an open access article distributed under the terms and conditions of the Creative Commons Attribution (CC BY) license (http://creativecommons.org/licenses/by/4.0/). 